\title{
FIFTY YEARS OF PROGRESS IN UNDERSTANDING ICE SHEETS
}

\author{
By GoRDON DE Q. ROBIN
}

(Scott Polar Research Institute, University of Cambridge, Cambridge CB2 1ER, England)

and Charles Swithinbank

(British Antarctic Survey, Natural Environment Research Council, Cambridge CB3 0ET, England)

ABSTRACT. Over the past 50 years, ideas relating to the physical features and dynamics of ice sheets have evolved materially, primarily due to modern technological advances in the acquisition of basic data. This paper therefore does not review contemporary knowledge but records how our perception of ice sheets has changed with time. Rather than dealing with individual contributions to the understanding of ice sheets, major topics and concepts are considered against a background of earlier ideas and theories.

Both the form and extent of the surface features of ice sheets have been defined more clearly by the relatively recent use of satellite studies (imagery and altimetry). In an analogous way, radio echo-sounding has enabled the accurate calculation of ice thicknesses and the mapping of the sub-ice bedrock contours, and hence estimation of the ice volume. Studies on the dynamics of ice sheets have been enhanced by bore-hole sampling of deep ice and the determination of ice-temperature distributions, coupled with measurements of mass balance and both surface and internal ice movement. Internal deformation of ice sheets, surging, and various flow theories are considered in relation to recent modelling studies. Global geophysics inevitably includes the role of ice sheets, and therefore climatological studies and new atmospheric chemistry data, together with information on the distribution of meteorites on the Antarctic ice sheet, are considered critically.

Modern concepts of the evolution of ice sheets have substantially modified earlier ideas of the glacial geologists and have explained much that had previously mystified them.

\section{INTRODUCTION}

This is not a review of contemporary knowledge but a brief history of how our perception of ice sheets has changed. So much has been learned in the last 50 years that a bibliography alone, without any other text, could fill this entire volume. In the space available we must be selective and inevitably subjective, so we deal primarily with major topics and concepts rather than individual contributions. Fifty years ago, the ice sheets covering Greenland and Antarctica were seen as relics of an ice age, little relevant to the physics or the history of European or North American glaciations. Today we see them as having been broadly in equilibrium with their climates throughout the period in which dramatic advances and retreats were taking place elsewhere. Models derived from recent progress in understanding present-day ice sheets have explained much that had mystified glacial geologists.

In the age of polar expeditions, progress was spasmodic and directly attributable to a particular expedition. Things changed little in a generation until the International Geophysical Year of 1957-58 ushered in an era of continuing progress that still shows no sign of faltering. Glaciology has evolved from a hobby of skiers to an accepted science with links to many other fields. It was the skiers, however, who provided the initial impetus for research and gave birth to the International Glaciological Society. The Association for the Study of Snow and Ice, as it was then known, was evidently so widely respected in 1939 that it was asked to propose a glaciological programme for the U.S. Antarctic Service Expedition of 1939-41. This it did, in some detail, and "final plans were based for the most part upon the suggestions of our British colleagues" (Wade, 1945, p. 160). This expedition, along with Wegener's Greenland expedition of 1930-31, Expéditions Polaires Françaises' work in Greenland and Antarctica from 1948 to 1952, and the Norwegian-British-Swedish Antarctic Expedition of 1949-52, laid the foundations from which later studies of ice sheets were developed.

We start by considering advances in the geographical field, then move on to geophysical topics. We conclude by surveying contributions that the study of ice sheets make to problems of global importance.

\section{SURFACE FEATURES}

\subsection{Surface form and extent}

While the general form of the surface of the Greenland ice sheet was known reasonably well in 1936, the central region of the Antarctic ice sheet was not explored until almost 20 years later.

In Figure la, we show Wager's (1933) contouring of the Greenland ice sheet based on sledge journeys up to 1931 , with modifications to include results in Lindsay (1935) of his crossing in 1934. Displacement of the $3000 \mathrm{~m}$ contour of central Greenland towards the east was attributed to the greater height and fewer gaps along the mountains on the east coast. Figure $1 \mathrm{~b}$ is based on Mock and Weeks (1965) and a Danish Geodetic Survey map of the same date. It shows the present map of the ice sheet north of lat. $72^{\circ} \mathrm{N}$., while to the south it agrees broadly with the more recent and detailed map of Figure 3a. Flow lines normal to the general contours are also shown on Figure $1 \mathrm{~b}$.

Little was known of the ice sheet of central Antarctica in 1936. A few explorers of the heroic age published perceptive deductions but no-one had crossed the continent. One-third of the coastline had not even been seen. Gould (1940) summarized what was known, noting that sledge journeys and flights had "all told, penetrated but a small part of this vast reservoir of ice. It remains still to be explored." Comparison of his flow-line map of Figure 2a with that of Drewry (1983) shows that intuition and extrapolation are no substitute for exploration. The 1983 map was compiled from 101000 elevation measurements from tractor traverses, aircraft flights, and surface elevations measured from randomly drifting balloons. The main ice divide of East Antarctica in Figure $2 b$ is seen to be more central than in Figure $2 \mathrm{a}$, and around $1000 \mathrm{~km}$ closer to the Indian Ocean than where it was believed to be a few years after the Society was founded. 

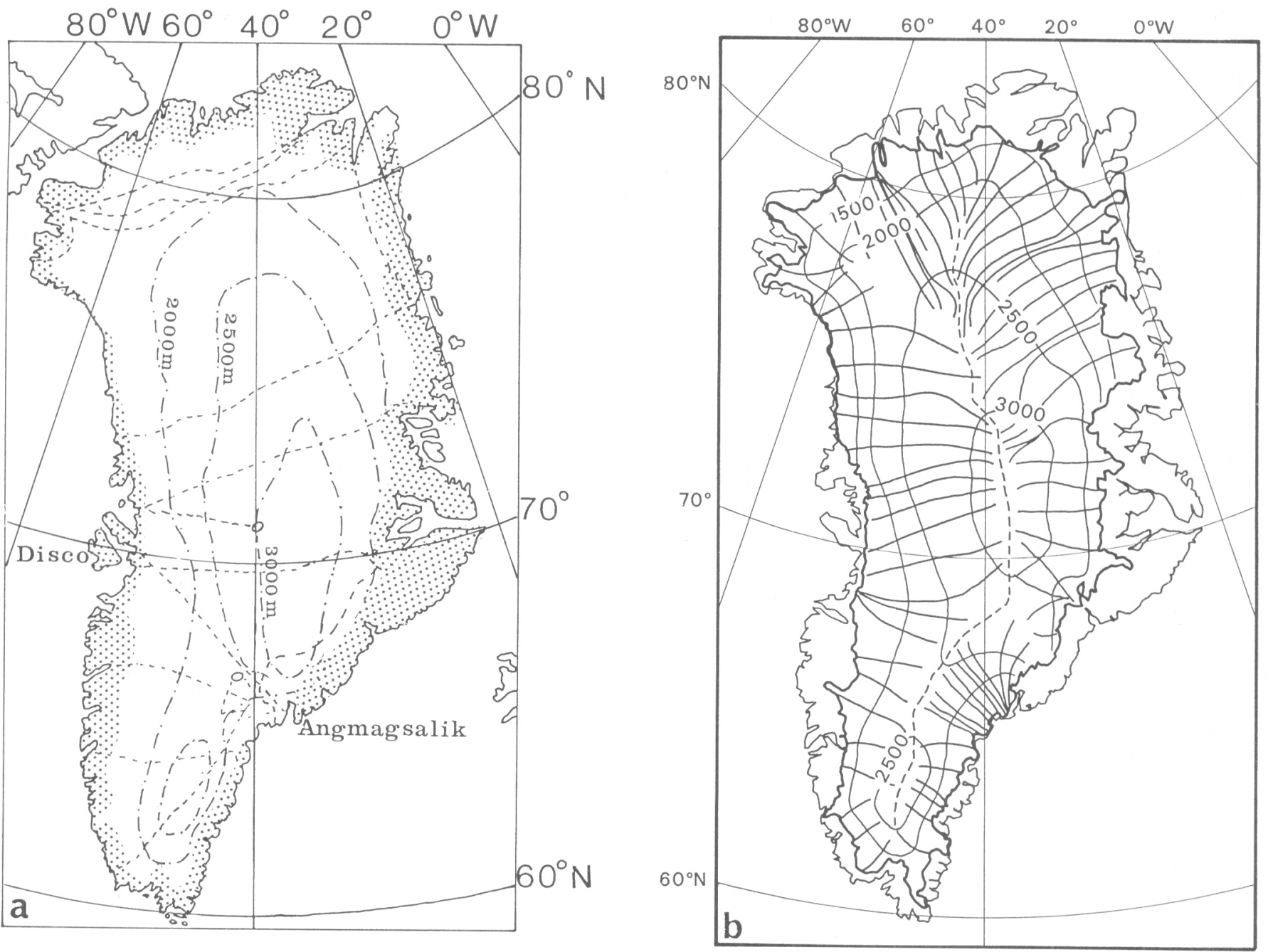

Fig. I. The Greenland ice sheet.

a. Surface form of ice sheet and exploratory journeys (short-dashed lines) from 1936 based on Wager (1933) in Wright (1937) with additional route and elevations from Lindsay (1935).

b. General surface form used in 1986 based on Mock and Weeks (1965) and the 1965 Danish Geodetic Survey map with addition of flow lines assumed normal to contours.
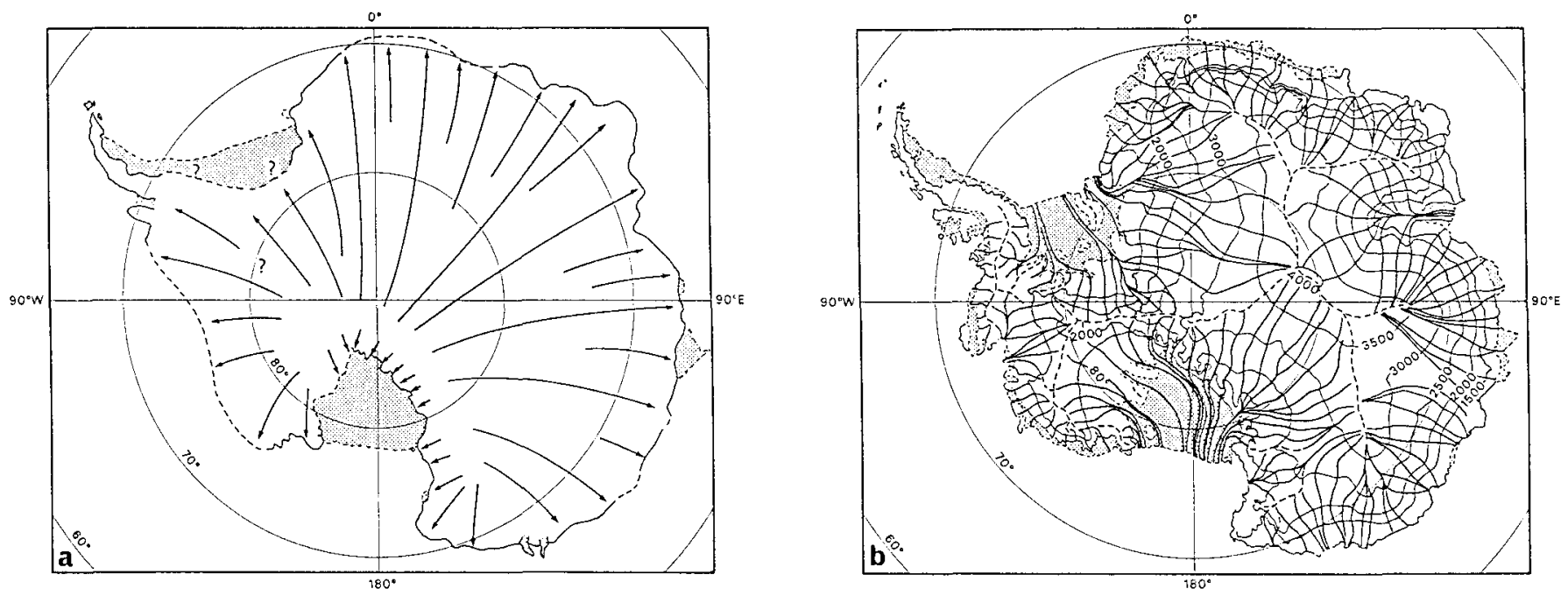

Fig. 2. The Antarctic ice sheet.

a. Known and postulated coastline and estimated flow lines from Gould (1940) interpreted from data available 50 years ago.

b. Current map of surface form and flow lines from Drewry (1983). 


\subsection{Satellite studies of surface form and extent}

\subsubsection{Satellite altimetry}

The use of satellite altimetry, first from Seasat as described in Brooks and others (1978), now provides a means of mapping the ice-sheet surface in great detail at high accuracy. So far, the data available lie between lat. $72^{\circ}$ north and south, the orbital limits of Seasat. After 1989, data to lat. $82^{\circ}$ should become available when the satellite ERS-1 is launched. Figure 3a, from $Z$ wally and others (1983), shows 100 and $50 \mathrm{~m}$ surface contours of the Greenland ice sheet south of lat. $72^{\circ} \mathrm{N}$. Similar maps have been produced for parts of the ice sheet in East Antarctica.

Figure $3 b$ shows a more detailed map in the vicinity of the ice divide of central Greenland around Crête station
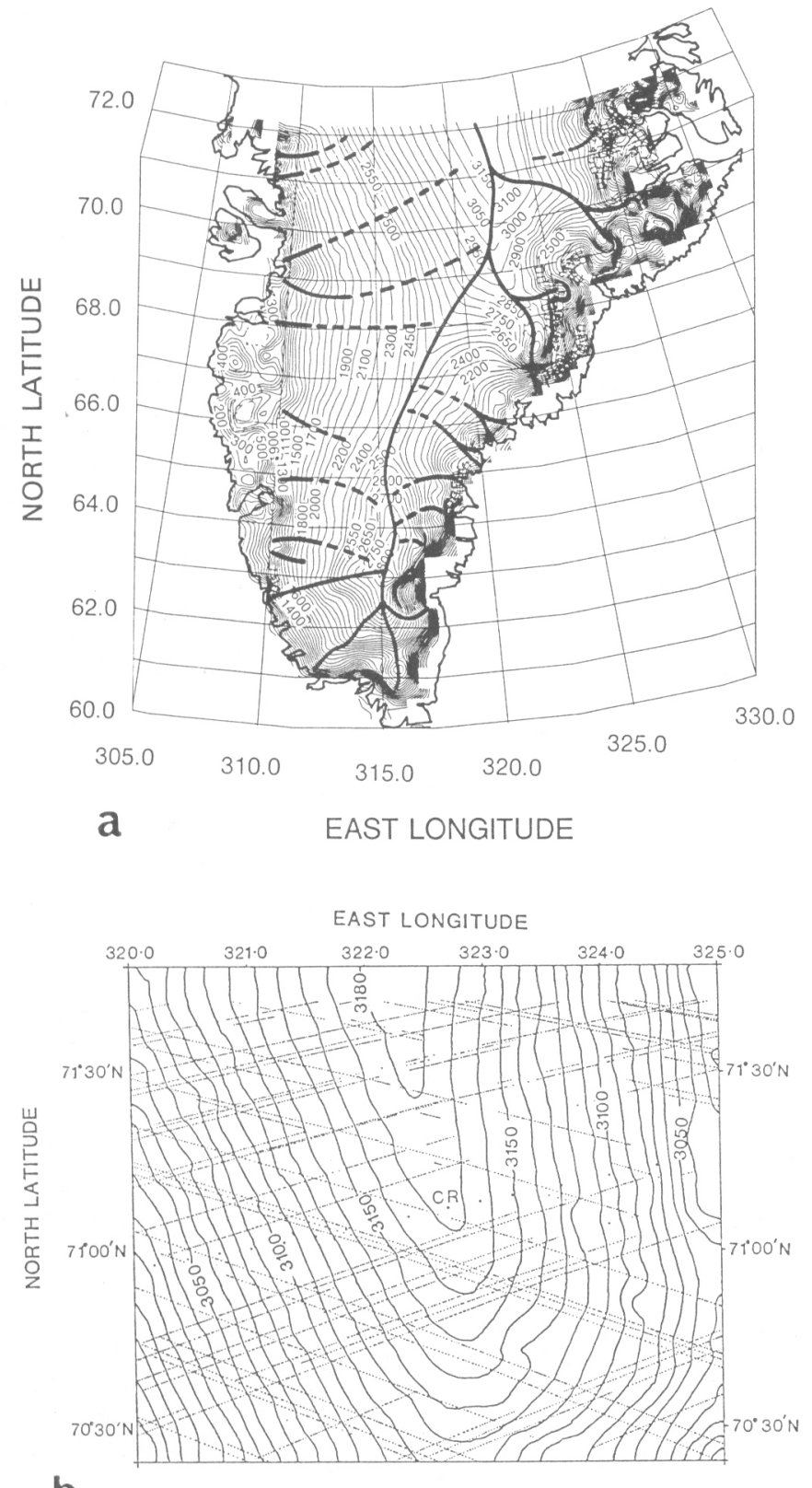

b

Fig. 3. Surface elevation of the Greenland ice sheet from satellite altimetry.

a. Surface elevations from Seasat radar altimetry showing $100 \mathrm{~m}$ contours to $2400 \mathrm{~m}$ and $50 \mathrm{~m}$ contours above that level. Delineation of major drainage basins based on surface topography by R.A. Bindschadler (from Zwally, 1984).

b. $10 \mathrm{~m}$ contours in the vicinity of the central ice divide near Crête station ( $C R$ on map). Dotted tracks show data points used for contouring. Based on an unpublished map of Gundestrup. (lat. $71^{\circ} 07^{\prime}$ N., long. $37^{\circ} 19^{\prime}$ W.). Data for Figure $3 a$ and $b$ come from unmanned orbiting satellites at a density two or three orders of magnitude greater than data used for Figure $1 \mathrm{~b}$ that came from the few traverses made in 1936.

The relative sharpness of the central ice divide and the smoothness of the surface in this region shown by the $10 \mathrm{~m}$ contours are shown clearly on Figure $3 \mathrm{~b}$. Since similar deviation from a straight line of the $100 \mathrm{~m}$ contours on Figure 3a represents a surface irregularity ten times greater than on Figure $3 b$, we can see that the surface undulations increase in magnitude considerably as one moves away from the ice divide. This is due to longitudinal stress gradients that increase with ice velocity and bedrock roughness away from divides. McIntyre (1985) has mapped such changes over much of the Antarctic ice sheet.

An important development is the planned use of satellites to monitor changes of the surface level of ice sheets to within a fraction of $1 \mathrm{~m}$ in order to determine where they are increasing or decreasing in volume.

\subsubsection{Satellite imagery}

Radiometers have been in operation for 25 years and now operate over many spectral bands between $0.2 \mu \mathrm{m}$ and $50 \mu \mathrm{m}$. Since 1972 , scanning micro-wave radiometers have revealed unexpectedly stable patterns of emissivity which have allowed useful extrapolation from the still sparse network of surface data on snow properties. Because the mean annual temperature and the accumulation rate of dry polar firn mainly determine the grain-sizes upon which the micro-wave emission depends, these two parameters account for the main features of the patterns observed over Greenland and Antarctica (Chang and others, 1976).

The Landsat series of satellites has contributed more to the knowledge of ice sheets than any other spacecraft before or since. Apart from early geographical discoveries (MacDonald, 1976), Landsat images have been used to identify and to provide data for planimetric mapping of the contemporary position of ice fronts, ice walls, grounding lines, surface features which can be used to define glacier units, ice streams, the direction of ice movement, crevassed areas which indicate regions undergoing rapid deformation, ice divides as defined by ridges, superimposed ice, surfaceequilibrium zones, ablation areas, and glacier surges (Swithinbank, 1985). The long-term average rate of movement of ice streams and ice fronts has been determined from time series of Landsat images. Large areas of blue (bare) ice have been discovered which are likely to be fruitful in the search for meteorites (Williams and others, 1983)

\section{ICE THICKNESS AND BEDROCK MAPPING}

\subsection{Geophysical surveys}

Knowledge of the thickness of ice sheets in 1936 is adequately covered by Flint's (1947) statement that the ice thickness was "almost wholly a matter of conjecture". For example, after noting the surface slope necessary to make the Greenland ice sheet flow outward, Croll (1879) applied this slope to Antarctica to calculate an ice thickness of 7 miles $[11000 \mathrm{~m}]$ at the South Pole, but gave 3 miles [4800 m] as a reasoned guess. Daly (1934) had suggested from geological evidence that the Wisconsin ice sheet had been $3000-4000 \mathrm{~m}$ thick. More typical estimates of mean ice thickness around 50 years ago were as low as $300-400 \mathrm{~m}$ for Greenland (Krüger, 1929), while for Antarctica a maximum mean thickness of $600 \mathrm{~m}$ was of ten conjectured (Flint, 1947; Odell, 1952).

The little evidence available in 1936 that has stood the test of time came from James Clark Ross (1847), who appreciated that the floating front of the Ross Ice Shelf was probably more than 1000 feet $[300 \mathrm{~m}]$ thick, and others such as Wright and Priestley (1922), who suggested a mean thickness of the ice shelf of $600-750$ feet [200 m] Wegener's Greenland expedition of 1930-31 (Sorge, 1933) made ten seismic ice-thickness measurements that showed bedrock fell back to within a few hundred metres of sea-level up to $120 \mathrm{~km}$ inland of the west coast mountains beneath ice up to $1850 \mathrm{~m}$ thick. Another measurement at Eismitte suggested a thickness of $1900 \mathrm{~m}$ (bedrock $+1100 \mathrm{~m}$ ), although they questioned this figure because of 
instrumental difficulties. Their measurements and those of Byrd's 1934-37 Antarctic expedition (Poulter, 1947) were not widely accepted by Earth scientists, while conjectures about the thickness of ice sheets had varied widely.

It was not until better seismic equipment became available after World War II that Expéditions Polaires Françaises in Greenland from 1948 to 1951 , and the Norwegian-British-Swedish Expedition (1949-52) in Antarctica produced convincing measurements (e.g. Holtzscherer and Robin, 1954) showing thicknesses of ice sheets up to $3 \mathrm{~km}$. The advent of the International Geophysical Year of 1957-58 then started a concerted international study of the Antarctic ice sheet that still continues. Seismic traverses were carried out by teams from Australia, Belgium, France, Japan, U.K., U.S.A., and the U.S.S.R. By 1970, these totalled more than $50000 \mathrm{~km}$ and gave a general picture of the thickness and bedrock relief of the ice sheet. Early maps by Thiel (1962) and in the Soviet Atlas of Antarctica (Bakayev, 1966) showed most major features that are now known. During these traverses, seismic measurements of ice thickness taken at intervals of $30-50 \mathrm{~km}$ were usually supplemented by gravity measurements at one-tenth that spacing to give a more detailed ice-thickness profile. These also showed that the Earth's crust was in approximate isostatic equilibrium with the ice loading (Bentley, 1964), in contrast with parts of the Northern Hemisphere where isostatic rebound is still taking place.

\subsection{Radio echo-sounding}

The technique of radio echo-sounding of ice thickness, first demonstrated by Waite and Schmidt's (1962) use of a $440 \mathrm{MHz}$ radio-altimeter to sound Antarctic ice shelves during the IGY, led to specific development of ice-sounding equipment by Evans in the Scott Polar Research Institute, Cambridge, and others. The principles and application of the technique have been described by Robin and others (1969) and by Bogorodskiy and others (1985). Antarctic expeditions using the technique include Australia, Britain, Japan, the U.S.S.R., while the most extensive surveys were made by the joint programme of the U.S. National Science Foundation, the Scott Polar Research Institute, and the Technical University of Denmark (see Fig. 4). Their results now cover half of the Antarctic continent with a grid spacing of 100 or $50 \mathrm{~km}$, while around one-third of the continent remains to be mapped at this density. Results are presented in Drewry (1983), who estimated the mean thickness to be $2160 \mathrm{~m}$ compared to Thiel's (1962) seismic-based estimate of $1810 \mathrm{~m}$. Sounding of the Greenland ice sheet has been less extensive, but again confirms the general features found by seismic surveys.

Most thicknesses measured by seismic and gravity sounding agree with radio-sounding results and with spot measurements at three deep bore holes drilled to bedrock. Errors in picking seismic reflections on noisy seismic records occurred in several cases, and some internal radio reflections from within ice shelves have been wrongly interpreted as bottom echoes. A few differences of less than $100 \mathrm{~m}$ probably indicate that radio and seismic energy can be reflected from different horizons near bedrock.

\subsection{Ice volume}

Loewe (1935) estimated the total volume of the Greenland ice sheet at $2.3 \times 10^{6} \mathrm{~km}^{3}$. Fifty years of subsequent research have raised the figure to $2.6 \times 10^{6} \mathrm{~km}^{3}$, an increase of 13\% (Budd and others, 1982). Before the IGY, Bauer (1955) estimated the volume of the Antarctic ice sheet to be $18.9 \times 10^{6} \mathrm{~km}^{3}$. The IGY seismic traverses (Thiel, 1962) served to raise the figure to $24.3 \times 10^{6} \mathrm{~km}^{3}$ and subsequent radio echo-sounding has added a further $24 \%$ to yield the current figure of $30.1 \times 10^{6} \mathrm{~km}^{3}$ (Drewry, 1983) although Radok and others (1986) give $24.4 \times$ $10^{6} \mathrm{~km}^{3}$

\section{ICE DYNAMICS: OBSERVATIONS}

\subsection{Introduction}

This section presents a range of glaciological and related field measurements which provide the factual basis of our perceptions of ice sheets. We deal separately with laboratory studies needed for development of theories and the resultant theories and hypotheses. These govern perceptions at a different level which may be more penetrating and can provide a unified picture of many field and laboratory studies.

\subsection{Surface net balance}

Although Sorge (1935) had earlier recognized annual snow strata in Greenland, the stratigraphical method of determining rates of snow accumulation did not come into its own until the pioneering studies of Schytt (1957) in the Antarctic and Benson (1961) in Greenland. These demonstrated that annual strata could be recognized even in the dry snow parts of ice sheets. A modern accumulation map of the Greenland ice sheet (Reeh, 1985) reveals rates varying from $150 \mathrm{~kg} \mathrm{~m}^{-2} \mathrm{a}^{-1}$ in the north to $2500 \mathrm{~kg} \mathrm{~m}^{-2} \mathrm{a}^{-1}$ in the extreme south. With this range it is little wonder that no earlier spot measurements could be used to derive a representative value for the whole ice sheet. Dividing the total accumulation ( $486 \mathrm{Gt} \mathrm{a}^{-1}$ ) by the area of the ice sheet $\left(1.7 \times 10^{6} \mathrm{~km}^{2}\right)$ yields a mean accumulation rate of $286 \mathrm{~kg} \mathrm{~m}^{-2} \mathrm{a}^{-1}$. Estimates for mean accumulation over the Antarctic ice sheet have ranged from a low of $70 \mathrm{~kg} \mathrm{~m}^{-2} \mathrm{a}^{-1}$ (Meinardus, 1938) to a high of $200 \mathrm{~kg} \mathrm{~m}^{-2} \mathrm{a}^{-1}$ (Kosack 1956), though most estimates are now close to $150 \mathrm{~kg} \mathrm{~m}^{-2} \mathrm{a}^{-1}$ (e.g. $143 \mathrm{~kg} \mathrm{~m}^{-2} \mathrm{a}^{-1}$; Giovinetto and Bentley, 1985).

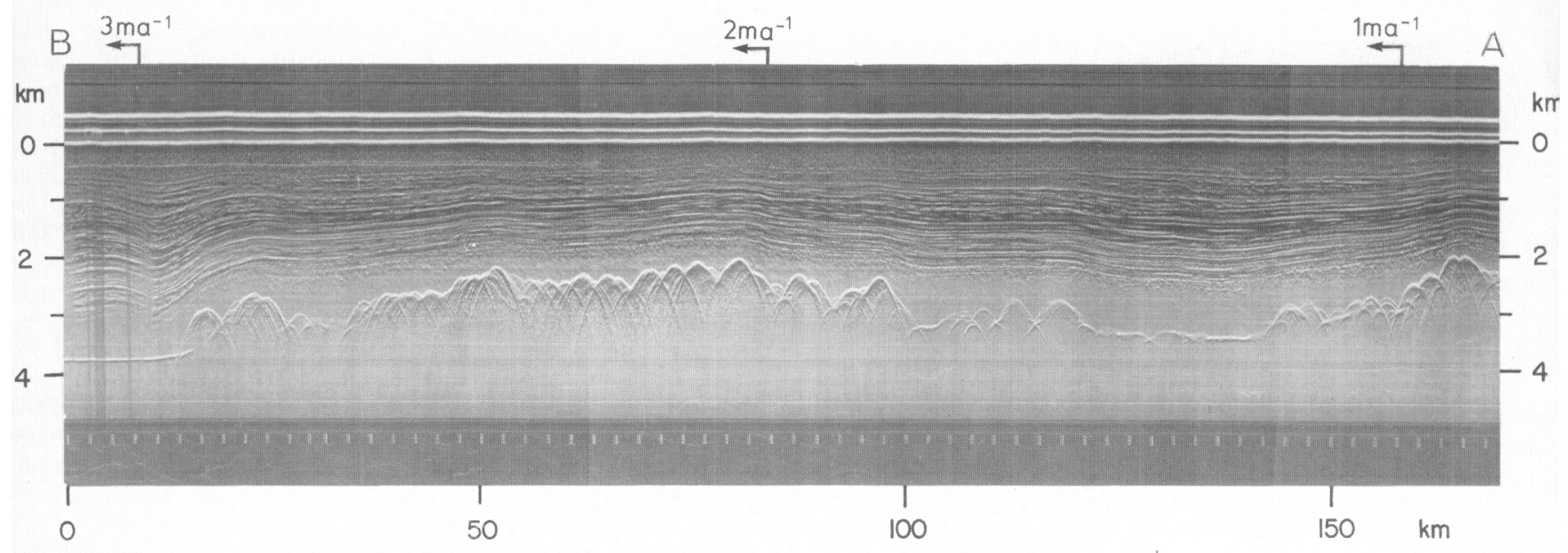

Fig. 4. Radio-echo profile from central Antarctica along the flow line $\mathrm{AB}$ of Figure 5. Flow starts from an ice divide 10 the right of the margin at $230 \mathrm{~km}$. On the left is a sub-ice "lake" near Vostok. Velocities of movement shown above the profile are estimated from a steady-state flow model and are consistent with that measured astronomically at Vostok. 
Extreme values in Antarctica range from over $1000 \mathrm{~kg} \mathrm{~m}^{-2} \mathrm{a}^{-1}$ to $25 \mathrm{~kg} \mathrm{~m}^{-2} \mathrm{a}^{-1}$ at high altitudes in central Antarctica.

Two major factors influencing the distribution of accumulation over ice sheets are seen when this is mapped. The first are the orographic effects which cause heavier snowfall where up-slope winds are predominant, as on the western half of Greenland (e.g. Schytt, 1974). The second is that the saturation water-vapour pressure of the free air exerts a major control on snowfall. At $-40^{\circ} \mathrm{C}$ this varies and is approximately halved for each $5 \mathrm{deg}$ decrease of temperature. In free air above the surface inversion, the moist adiabatic lapse rate is around $0.6 \mathrm{deg} / 100 \mathrm{~m}$ altitude We therefore expect accumulation to halve for each $830 \mathrm{~m}$ increase of surface elevation, a figure that applies approximately over East Antarctica above say $1500 \mathrm{~m}$. Effects of latitude and continentality on temperature and precipitation tend to be obscured by orographic effects.

The above argument has been applied to the variation of accumulation with time as well as location. During an ice age when global air temperatures fell by around $5 \mathrm{deg}$, we should therefore expect net accumulation over central Antarctica to be halved (Robin, 1977). This has been confirmed by data from the Vostok ice core discussed in section 6 (Lorius and others, 1985; Yiou and others, 1985).

\subsection{Basal net balance}

Although observations are few, we now know from related studies of temperature gradients and of the structure of basal ice and its debris content that both melting and freezing occur at the base of the ice sheet. This is due to geothermal and frictional heating and freezing by thermal conduction in certain conditions. Zotikov's (1963) analysis suggests that melting averaging 2 or $3 \mathrm{~mm} \mathrm{a}^{-1}$ takes place under a region approaching half the area of the Antarctic ice sheet while elsewhere bedrock is frozen. This gives a mean value of basal melting of the order of $1 \%$ of surface accumulation. For Greenland the proportion is much less.

In contrast with the above, basal melting and freezing beneath ice shelves can exceed the surface net balance. There is considerable transfer of ice mass associated with latent-heat transfer by ocean currents beneath the ice. It is the counterpart of atmospheric transfer of ocean water evaporated into the atmosphere and later deposited as snow on ice sheets. When the temperature of ocean water moving beneath ice shelves is above the freezing point of sea-water, basal ice is melted. The freezing point is pressure-dependent and ranges from about $-1.9^{\circ} \mathrm{C}$ at atmospheric pressure to about $-2.8^{\circ} \mathrm{C}$ under an ice shelf $1200 \mathrm{~m}$ thick, depending on salinity. Latent heat absorbed in melting ice beneath a thick ice shelf can be liberated with ice re-forming as water moves from high-pressure (deeper) regions to lower pressures (Doake, 1976). Both temperature and ice-core analyses suggest that up to $0.5 \mathrm{~m} \mathrm{a}^{-1}$ is added by the process beneath some parts of the Amery and Ronne Ice Shelves (Morgan, 1972; Engelhardt and Determann, 1987). However, net overall melting must occur, and this has been estimated at $30-50 \%$ of the total mass input to the Ross Ice Shelf and up to $70 \%$ of that to the Filchner-Ronne Ice Shelves (Doake, 1985). Although the possibility of extensive basal melting was recognized by some workers up to 1960 , for example, in Buynitskiy (1960), it was largely overlooked for the next two decades. Attention has again been given to the problem during the current decade by both glaciologists, such as Potter and Paren (1985) whose measurements show a mean melting rate of around $2 \mathrm{~m} \mathrm{a}^{-1}$ beneath George VI Ice Shelf, and by shipborne measurements of salinity and temperature changes with depth off the fronts of the Filchner-Ronne Ice Shelves (Foldvik and others, 1985) and the Ross Ice Shelf (Jacobs and others, 1985).

\subsection{Mass balance}

Over the past 40 years many calculations of the mass balance of contemporary ice sheets have been published. They give a broad indication of magnitudes of annual accretion and loss of mass of the two major ice sheets. The variability of both terms over the two vast ice sheets, together with errors and unknown factors such as melting beneath ice shelves, are such that estimates of the balance between input and loss are of little value. Estimates for
Greenland lie within the range $515 \pm 115 \mathrm{~km}^{3} \mathrm{a}^{-1}$ for accumulation, $325 \pm 105 \mathrm{~km}^{3} \mathrm{a}^{-1}$ for melting, and $240 \pm$ $80 \mathrm{~km}^{3} \mathrm{a}^{-1}$ for iceberg discharge. Over the much larger area of Antarctica, there is less variation between most recent estimates of accretion, mainly because everyone extrapolates from the same data input to cover blank spaces on the map. A figure of around $1800 \mathrm{~km}^{3} \mathrm{a}^{-1}$ to $2000 \mathrm{~km}^{3} \mathrm{a}^{-1}$ is most common for total accumulation, while mass losses by discharge to the sea run from around half to double this figure.

While the figures above suggest that we do not know whether these ice sheets are increasing or decreasing in mass, some progress can be reported. Some mass-balance figures for individual drainage basins or regions have much lower proportional errors. Hamley and others (1985), using satellite-derived ice velocities over part of the IAGP study area of East Antarctica between long. $90^{\circ} \mathrm{E}$. and $135^{\circ} \mathrm{E}$. and north of lat. $80^{\circ} \mathrm{S}$., found this part of the ice sheet unlikely to be significantly out of balance $( \pm 10 \%)$. Budd and Smith's (1985) recent assessment incorporating much improved data from the previous decade gave losses less than an input of around $2000 \mathrm{~km}^{3} \mathrm{a}^{-1}$ by 0 to $20 \%$. Shabtaie and Bentley (1987), however, have shown that basins feeding Ice Streams $B$ and $C$ in West Antarctica have large negative and positive balances, respectively.

Analysis of several deep bore-hole temperature profiles in Antarctica suggests a slightly positive mass balance (Robin, 1970; Ritz and others, 1982). They indicated that over millennia, mean thickness increases at Byrd Station and Dome $C$ have not exceeded the annual accumulation by more than $20 \%$. Interpretation of $\delta^{18} \mathrm{O}$ data as a proxy indication of surface temperature leads to a similar conclusion.

\subsection{Ice movement: surface}

During the past 50 years much research has attempted to answer the question "How fast do polar ice sheets flow?" Scattered measurements show that the down-slope component of movement increases from close to zero at most ice divides to as much as $7 \mathrm{~km} \mathrm{a}^{-1}$ on parts of the fastest outlet glacier (Jakobshavns Isbræ, Greenland). Until the development of satellite Doppler-positioning techniques, most measurements were confined to the peripheral parts of the ice sheets where flow could be easily determined in relation to fixed points on rock (Swithinbank, 1963; Bauer and others, 1968). Despite enormous difficulties, classical triangulation and trilateration techniques were subsequently used to extend velocity measurements inland (Bauer and others, 1968) and away from fixed points (Dorrer and others, 1969). Satellite methods have revolutionized the measurement of ice-surface velocity because they can be used to determine coordinates in three dimensions at any point on an ice sheet. Drew and Whillans (1984) claimed position errors of less than $0.2 \mathrm{~m}$ close to the ice divide in southern Greenland. A comprehensive set of ice-velocity and thickness data was used to calculate mass balance and ice flow-law parameters over parts of East Antarctica (Hamley and others, 1985) and at a stake network extending over almost the whole area of the Ross Ice Shelf (Thomas and others, 1984).

However, relatively few direct measurements of ice movement have been made over most of the ice sheets. Other evidence from temperature profiles and studies of ice cores confirms to a first approximation that outflow of the ice sheet from central regions is roughly in balance with the surface accumulation over many, but not all, accumulation basins of the ice sheet of Antarctica. More field data from Greenland, as well as Antarctica, along with theoretical modelling and computer analyses are necessary before we will know whether individual basins of the ice sheets are in balance with the ice input.

\subsection{Ice movement: internal}

There have been few measurements of internal deformation of bore holes in ice sheets to provide comparable information to that from many valley glaciers, mainly in temperate ice. Garfield and Ueda (1976) measured the change of tilt of the Byrd Station bore hole from 1968 to 1975 . Below around $1100 \mathrm{~m}$ the changes were in the same azimuth as the surface movement determined by 
Whillans (1983). At smaller depths where tilting was less, it differed by over $90^{\circ}$ in azimuth from deeper layers.

Some indication of internal deformation is also given by deformation of internal sedimentary layering seen on radio-echo records (Fig. 4), especially on deep ice of central Antarctica. Robin and others (1977) found that to a first approximation $( \pm 10 \%)$, vertical strain-rates of the top $80 \%$ of the ice column were approximately uniform $( \pm 10 \%)$, as ice moved over bedrock relief variations of over $1 \mathrm{~km}$ in height with ice thickness up to $3.5 \mathrm{~km}$ along a $230 \mathrm{~km}$ flow-line profile. Slope variations of the lowest layer along the profile were often less than one-fifth of those of the bedrock surface. This indicates that large variations of basal shear must occur at lower levels, in contrast to the relatively uniform vertical strain-rates in cold ice at upper levels. Other records of layer deformation around steep subglacial peaks show a strong deformation in three dimensions, with much of the deformation being preserved in ice further down the flow line (Robin and Millar, 1982).

\subsection{Temperature distribution}

Although the extremely low temperatures of surface layers of the ice sheet were so well known to the early explorers, and had been measured to $17 \mathrm{~m}$ depth at Eismitte by Sorge and to $41 \mathrm{~m}$ by Wade at Little America in 1940 , temperatures in the deep interior of the ice sheet received little consideration. Probably, if thought about 50 years ago, it was assumed that everywhere below a certain depth the ice would be at pressure melting-point. The changed perception was stimulated by bore-hole temperature measurements of the French across central Greenland in $1948-51$ and by the NBSAE to $100 \mathrm{~m}$ depth at Maudheim. The different temperature gradients in different locations were explained to a first order in terms of a steady-state model that took account of downward advection of cold ice. This suggested basal temperatures below freezing point beneath central Greenland (Robin, 1955). At the same IUGG meeting in Rome where this was first presented, Haefeli, on the basis of basal ice stresses and Holtzscherer's seismic refraction shooting results, concluded that the basal ice temperature of central Greenland was below freezing point.

Appreciation that mean temperatures of polar ice sheets could depend more on the surface than basal (melting?) temperature stimulated development of radio echo-sounding techniques. Successful radio echo-soundings in north-west Greenland in 1964 showed the validity of the concept. More direct evidence came when deep bore-hole temperatures to bedrock were obtained at Camp Century in 1966 and at Byrd Station in 1968, the former with a temperature of $-13.0^{\circ} \mathrm{C} 17 \mathrm{~m}$ above bedrock, and the latter, as expected, at the pressure melting-point $\left(-1.6^{\circ} \mathrm{C}\right)$. Since this start, more deep bore holes have given further and more accurate data while theory and calculations have been improved to take account of basal melting or freezing, more realistic internal deformation models, and variations with time of the climate, size, and flow of ice sheets. Figure 5 shows $10 \mathrm{~m}$ and deep ice temperatures now measured on the Antarctic ice sheet. The varied profiles can all be explained by available theory - at least to a first order. The strongest gradients are found at the base of ice shelves where much melting takes place - the smallest basal gradients are also on an ice shelf (Amery) where basal accretion of ice (see section 4.2) is estimated at around $0.5 \mathrm{~m} \mathrm{a}^{-1}$. Development of computer techniques has made possible close matching of temperature profiles to realistic input figures for accumulation, boundary temperatures, and ice flow (Budd and others, 1971). Improvements on first-order calculations have resulted from using a temperature input derived from stable isotopic ratios $\left(\delta^{18} \mathrm{O}\right)$ together with better strain-rate/ice-flow modelling (Budd and Young, 1983; Jenssen and Campbell, 1983). The improved agreement between computed and observed temperature profiles shows the approximate validity of the use of isotopic values as indicators of past surface temperatures back into the last ice age.

\subsection{Bore-hole sampling of deep ice}

Development of ice-coring techniques since 1950 has provided ice-core samples down to bedrock at Camp Century and Dye 3 in Greenland, at Byrd Station,
Antarctica, and to similar depths at Dome $C$ and Vostok in East Antarctica. Although the latter two did not reach bedrock, the Vostok core has produced the oldest ice with almost continuous sampling from the surface to $2083 \mathrm{~m}$ depth where the ice is around 160000 years old. We discuss geochemical studies of these ice cores in section 6 .

The importance of core samples to ice dynamics comes from provision of material on which deformation studies for determining stress/strain-rate relationships can be carried out. The dependence of this relationship on temperature, crystal structure (crystal size and fabric orientation) can all be determined in the laboratory on field samples as distinct from laboratory-grown ice. This has been particularly important in relation to development of strong crystal orientation that increases the deformation by shear along easy glide planes by a factor of up to five times, while fine-grained crystal fabric resulting from deposition during ice ages also increases deformation rates considerably. Changes of crystal size and an increasingly random orientation in the lowest few hundred metres of the Byrd Station core suggest a lower rate of deformation occurs in the lowest layers - an effect not expected from simple theory.

Another potentially useful parameter obtained from ice cores is measurement of their total gas content. This provides a pressure-altimetric record of the altitude at which air bubbles were trapped in the ice, and hence a record of former surface elevations at which sections of the ice core were deposited (Raynaud and Lebel, 1979; Jenssen, 1983). Further verification is needed before we know in which locations such deductions are acceptable.

\subsection{Glacial geology}

Fifty years ago, concepts on the dynamics of ice sheets were mainly based on observations of glacial geologists. In his book The Quaternary ice age, Wright (1937) said, concerning the essential distinction between mountain glaciers and ice sheets, "In the physics of their nourishment and depletion and above all in their physiographical and geological effects, these two types of accumulation exhibit fundamental differences. It might almost be said that they have little in common except the possession of a pseudoplastic motion under the action of gravity, which is the property of all ice masses large and small". In 1936, studies of glacial geology were almost entirely confined to evidence of terrestrial deposits and erosion by former ice sheets. Much information has been added during the past 50 years by marine geologists analysing cores obtained from the ocean floor. Instead of three or four Pleistocene glaciations in the Northern Hemisphere, marine geologists have shown that a whole series of glaciations in the Northern Hemisphere started around $2.4 \mathrm{Ma}$ ago. They increased in magnitude around $0.7 \mathrm{Ma}$. They show dominant periodicities around 100,40 , and $23 \mathrm{ka}$, which are similar to those of radiation changes at high latitudes due to orbital changes of the Earth in regard to the Sun (Hays and others, 1966).

Another input from some glacial geologists and some physical glaciologists is the direct study of carriage and deformation of basal till within and beneath glaciers. Until recently, such studies beneath ice sheets were limited to examining basal layers in cores from the few drill holes that have reached bedrock. Recently, seismic studies in Antarctica have shown that deformation of very soft till beneath Ice Stream B in Byrd Land (Blankenship and others, 1986) can explain the high surface velocities. Evidence of block transport of large amounts of soft till beneath former ice sheets of Europe over considerable distances may also be due to rapid deformation within the till.

During the past 40 years, measurements of processes and theoretical advances in ice dynamics have dominated the attention of physical glaciologists to such an extent that, with a few notable exceptions (see Boulton, 1987), the potential contributions of glacial geology to our understanding of ice dynamics have been overlooked.

\section{ICE DYNAMICS: HOW AND WHY}

\subsection{Introduction}

In order to understand the links between different 


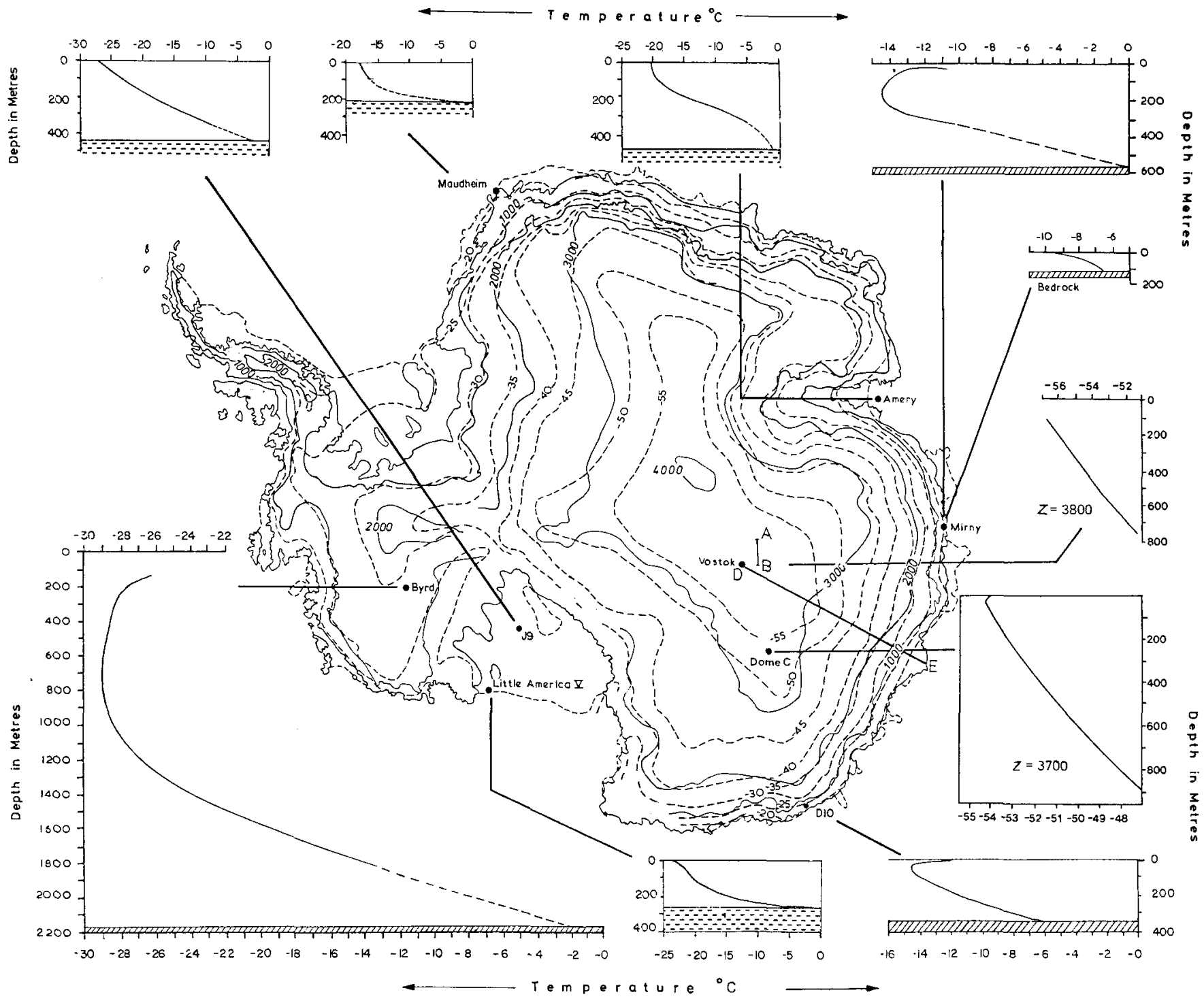

Fig. 5. Antarctic ice sheet, showing elevation contours, isotherms of $10 \mathrm{~m}$ depth temperatures (mean annual), and measured temperature-depth profiles (from Robin, 1983). Line AB shows location of radio-echo profiling in Figure 4. Line DE shows the location of the profile in Figure 6.

observations on ice sheets we need to develop theories of ice dynamics. These should cover various aspects of their flow, form, and interactions with the atmosphere, oceans, and solid earth. We should then be able to use the theories to improve interpretation of evidence of former glaciations, to predict future changes of ice cover and its role in the future global climate. We are unlikely to do this effectively until we have a comprehensive understanding of the dynamics of present-day ice sheets, although a limited understanding can help on some problems. Croll's (1879) estimate of ice thickness at the South Pole is one early example.

A simple assumption is that since the basic physics of ice does not change with time, former ice sheets will have had similar characteristics to present-day ice sheets, especially the relationship of volume to area. On this basis, Donn and others (1962) estimated sea-level lowering during the last glacial maximum from the known area of former ice sheets and hence their volume. Their figure for sea-level lowering of $137-159 \mathrm{~m}$ agrees roughly with subsequent evidence from ${ }^{14} \mathrm{C}$ dating of submerged beaches and coral reefs. Such a general relationship is not, however, applicable everywhere. When basal sliding occurs or when ice is carried along on deforming basal sediments, ice-surface slopes and hence ice-sheet volumes can be much smaller. Until we have better theories of basal sliding and of deformation of sub-ice sediments and of their consequent interaction on the internal deformation of ice sheets, our knowledge of the dynamics of ice sheets will not provide a satisfactory basis for forecasting. The same is true to a lesser extent in regard to the internal deformation of ice masses.

\subsection{Extrusion flow and later theories}

Fifty years ago the concept of extrusion flow was receiving attention. In the first issue of the Journal of Glaciology (Vol. 1, No. 1, 1947, p. 12-21), a paper "Extrusion flow on glaciers" recorded a discussion of 26 April 1946 led by Seligman. High pressures at depth in glaciers were believed to cause ice to deform more easily so that it was extruded under the weight of overlying ice. Demorest (1943) postulated that the enormous ice streams of the Greenland fjords must be fed by extrusion from the centre of the ice sheet. Streiff-Becker (1938) considered the measured accumulation on a Swiss glacier was being carried away more quickly than was indicated by measured surface flow, which pointed to extrusion flow.

To test the extrusion-flow hypothesis, the technique of measuring changes with time of the tilt of a vertical bore hole was developed (Perutz, 1950) in order to determine the vertical distribution of the down-slope velocity of glaciers. This led to rejection of the extrusion-flow hypothesis and was one of several major changes affecting our perception of ice sheets during the following decade. Another factor helping these changes was the increased use of steady-state models since 1950 which made it possible to produce 
analytical solutions to problems of ice dynamics and thermodynamics. In these solutions, parameters such as accumulation rate, thickness, velocity, and temperature do not change with time at any point in a glacier or ice sheet. This concept, along with much improved information on the physical properties of ice, stimulated various changes. Careful laboratory studies of the deformation properties of polycrystalline ice, first by Glen (1955), and then by others, showed that strain-rates varied as the third or fourth power of the applied stress as well as being strongly dependent on temperature. Field studies confirmed these findings and led to the introduction of new theories treating ice as a plastic material or with a realistic flow law instead of the linear relationship of Newtonian viscosity. Nye (1951) pointed out that the relevant stresses were, as in metallurgy, the deviatoric stresses and that hydrostatic stresses had little or no effect. Rigsby (1958) showed this to be the case by laboratory experiments.

Nye $(1951,1952)$ showed that the thickness $(h)$ of an ice sheet at any point was inversely proportional to surface slope $(\alpha)$ and that the basal shear stress $\left(\tau_{b}\right)$ was given by

$$
\tau_{\mathrm{b}}=\rho g h \sin \alpha .
$$

This result was derived from both plastic and Glen's flow laws and has dominated glaciological theory since its introduction. Prior to use of surface slopes in Equation (1), the role of bottom slopes and the down-slope component of weight on bedrock received more attention. Both approaches are now used, although emphasis on the role of bedrock is largely confined to theories related to mountain glaciers. Field results from ice sheets showed that Equation (1) only applies to mean slopes over distances an order of magnitude greater than the ice thickness. At shorter distances, the surface slope of ice sheets is strongly influenced by gradients of longitudinal stress, as shown by theoretical and field studies around 1967-71. Values of $\tau_{\mathrm{b}}$, which usually lie between 0.5 and $1.5 \mathrm{bar}(50-150 \mathrm{kPa})$ on most glaciers and ice sheets, fall to much lower values on rapidly flowing ice streams and outlet glaciers of the Antarctic ice sheet and to zero beneath floating ice shelves. Deformation is then related to principal deviatoric stresses $\sigma_{x}^{\prime}, \sigma_{y}^{\prime}, \sigma_{z}^{\prime}(x$-axis in the flow direction - horizontal or tilted parallel to the mean surface or basal slope). A theory of ice-shelf flow linked to Glen's law was presented by Weertman (1957[a]), and modified by Budd (1966), Thomas (1973[a], [b]), and Sanderson (1979) to take account of lateral and other restraining forces. A forerunner to these modifications was Crary's (1966) "Mechanism for fjord formation indicated by studies of an ice-covered inlet".

\subsection{Sliding and internal deformation}

The question of how much the motion of large ice sheets is due to internal deformation and how much to sliding has not been fully solved. It is clear that fast motion of ice streams and trunk glaciers is dominated by sliding as surface slopes are too small to generate stresses needed to produce observed surface velocities by internal deformation. An empirical plot of many ice-surface velocities $\left(V_{\mathrm{i}}\right)$ divided by ice thickness $(z)$ by Budd and Smith (1981) was related to basal shear stress $\tau_{b}$ by

$$
V_{\mathrm{i}} / z=K \tau_{\mathrm{b}}{ }^{n}
$$

where $n$ and $K$ come from Glen's relation $\dot{\varepsilon}=K \sigma^{n}$ and $V_{\mathrm{i}} / z=\dot{\boldsymbol{\epsilon}}_{x y}$ is the mean shear rate through the ice column if there is no basal sliding. A plot of data from a variety of sources on polar ice gave $n=3.5$ and $K=0.025 \mathrm{bar}^{-n} \mathrm{~m}^{-1}$. Hamley and others (1985), using data from a sector of East Antarctica between Dome $\mathrm{C}$ and the coast, gave $n=3.21$ and $K=0.023 \mathrm{bar}^{-n} \mathrm{~m}^{-1}$. The values of $n$ are close to those of Glen and many values derived from internal deformation of glaciers, while that for $K$ is that to be expected of polycrystalline ice some degrees below freezing point. If the motion had been dominated by sliding, we would have expected a relationship such as $V_{\mathrm{i}} \propto \tau_{\mathrm{b}}{ }^{2}$ based on the sliding theory of Weertman (1957[b]) and others or $V_{\mathrm{i}} Z^{*} \propto \tau_{\mathrm{b}}{ }^{3}$ (Budd and Smith, 1981) based on laboratory experiments where $Z^{*}$ is the equivalent normal stress on the bed (weight of overlying ice minus basal water pressure). Although it is clear from observation of sub-ice water masses that $\tau_{b}$ varies widely at the bed of polar ice sheets (Whillans and Johnsen, 1983), flow of the inland section of major ice sheets does appear to be dominated by internal shear deformation within the lower layers of ice, as described in Nye (1959), while the principal stresses are dominant in upper layers. The resultant deformation is not that different from sliding at an interface, since we have very strong shear deformation $\dot{\varepsilon}_{x y}$ in the lowest $10 \%$ or so of the ice sheet, but little shear $\dot{\varepsilon}_{x y}$ in upper layers where longitudinal deformation is dominated by principal stresses.

The transition from motion by internal shear to motion by sliding frequently takes place where ice enters trunk glaciers and moves from a roughly horizontal bed over a steep bedrock scarp which is effectively the headwall of an ice-filled fjord (McIntyre, 1985). The observed presence of extensive water at the base of the ice on radio-echo records near this point, as well as the sharp decrease of surface slope down-stream, both indicate the onset of sliding. Association of this onset of sliding with a sudden increase of bedrock slope is not covered by accepted theories of sliding which require modification. Similarly, too much weight should not be given to numerical values of $K$ obtained by empirical fitting of observations to Equation (2), since other effects than temperature operate, such as easy gliding with a strongly oriented crystal fabric or changes of ice rheology with crystal size and dust content.

\subsection{Surging}

No glaciers or ice sheets are in a completely steady state, but for many the inter-annual variations cause rather limited changes of flow. Many surging valley glaciers, in contrast, are quiescent over some decades before their flow increases by one or two orders of magnitude for a year or more. The repetitive cyclic surging history of such glaciers suggests that an internal mechanism rather than external forcing is usually the dominant cause, although this is not always the case.

Wilson (1964) suggested that massive surging of the Antarctic ice sheet could take place and be responsible for global ice ages during the Pleistocene. This has stimulated much work, both theoretical and in the field, but no fully convincing field evidence has been provided of such massive surging. Theories and computing models that produce surges have been produced, as well as studies showing that certain types of instability are unlikely. Such theories do not prove or disprove existence of massive surges of continental ice sheets or the correctness of the theories. Field evidence from temperature and isotopic profiles in polar ice sheets provide no support for the hypothesis. Dynamic observations thought to provide support for surging of large basins of the Antarctic ice sheet have not withstood further examination. Only one convincing case (Ice Stream $\mathrm{C}$ of Byrd Land) of a surge involving a discharge of the order of $10^{4} \mathrm{~km}^{3}$ some 300 years ago has been provided to date. While other cases will no doubt be found in the future, the Ice Stream $C$ surge involved a volume about five times the annual discharge of ice from the continent or around $0.04 \%$ of the total mass of the ice sheet. This is of little climatological significance.

\subsection{Publications}

It is impracticable in a review of this length to do justice to all the theoretical laboratory and computing studies that have advanced our knowledge of glaciology rapidly during the past four decades. Perceptions of ice physicists have resulted from laboratory work as well as theoretical models, those of mathematicians from more complex and mathematically rigorous approaches, and by improving knowledge of boundary conditions. Much remains to be done.

Widespread changes of perception are perhaps shown most clearly when knowledge moves from the realm of research papers to its incorporation in textbooks for students and research workers. An exhaustive list would be invidious, but textbooks that include substantial discussions on the dynamics of ice sheets include those by Shumskiy (1964), Lliboutry (1964-65), Paterson (1969, 1981), Colbeck (1980), and Hutter (1983). Books that record advances in knowledge of the basic physics and physical chemistry of ice include 
Dorsey (1940), Pounder (1965), Fletcher (1970), and Hobbs (1974).

\subsection{Modelling studies}

The rapidity with which one can set up finite-element or other other models to provide numerical answers from glaciological theories has contributed to our understanding of ice sheets in recent years. The main value of a computing study is usually in the evidence it gives on the effect of changing certain parameters or of the relationship between several parameters. Furthermore, the results can be no better than the information fed into the models, and this can be unsatisfactory as mentioned in section 5.3 in relation to sliding and surging glaciers.

An outstanding early computing study was "The derived physical characteristics of the Antarctic ice sheet" by Budd and others (1970). Figure 6 from this study illustrates some points in the preceding paragraph. They used a simplified moving vertical column model, the steady-state assumption applied to the present surface and bedrock profiles, and all available information on the present surface-accumulation rates and temperature. The results show the resultant particle trajectories, temperature-depth profiles, and isochrons of former surface layers in later millennia.

The temperature-depth curves in Figure 6 provide a good qualitative and a rough semi-quantitative three-dimensional fit to the temperature observations in Figure 5. The shape of the isochrons is similar to the radio-echo layering of Figure 4 . This provides an impressive justification of the theory of ice dynamics used as a basis for modelling. However, calculated basal temperatures from 0 to $900 \mathrm{~km}$ are well below freezing point, whereas radio echo-soundings in the region of Vostok indicate the presence of extensive basal melting and sub-ice water. The discrepancy appears to be due mainly to use of too high values of accumulation rate in modelling. More recent figures from field measurements would have predicted basal melting. Some changes of ice thickness and uncertainty over values of geothermal and frictional heat supply also add uncertainty to numerical values from modelling. Unfortunately, the above modelling results led to the proposal that, because the base of the ice sheet of central Antarctica was frozen, it would be a suitable place for dumping radioactive waste with a long half-life - a proposal that was dropped when later evidence became available.

Whillans (1976) also showed the value of modelling studies, even though the final answer was not fully satisfactory on a quantitative basis. He used similar input parameters to Budd and others (1971) for Figure 6, together with his measured surface velocity and strain-rate data on the flow line leading to the Byrd Station bore hole. Whillans' calculated shapes of the $30 \mathrm{ka}$ and other isochrons showed good agreement with the observed form of radioecho layering along the same $300 \mathrm{~km}$ profile. It was

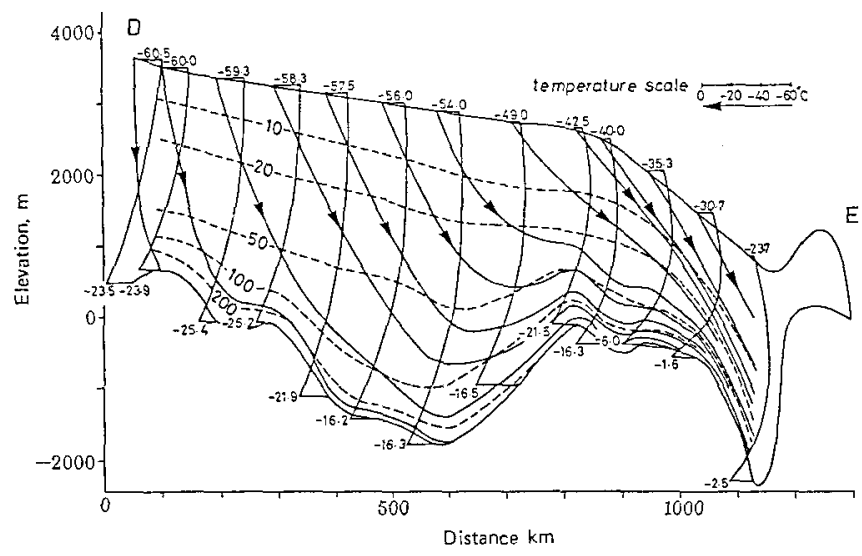

Fig. 6. Calculated particle paths (arrows), isochrones (dashed lines, ages in $10^{3} a$ ), and temperature-depth profiles (full lines, temperatures in ${ }^{\circ} \mathrm{C}$ ), assuming steady-state conditions along profile from Vostok to Wilkes Station (from Budd and others, 1971). concluded that the thickness and flow of the ice sheet had not changed to any extent over the past $30 \mathrm{ka}$. While this is probably correct regarding thickness and form of the surface and isochrons, later studies suggest that the dating and flow rates may well be out by up to $50 \%$.

Similar problems arise with modelling of former ice sheets. Reasonable limits to the rates of growth and decay of Pleistocene ice sheets can be computed on the basis of probable input parameters, but results are not precise (Weertman, 1964). Basal temperatures and related erosion patterns can be computed on a broad regional basis. The effect of isostatic rebound in accelerating retreat of large Northern Hemisphere ice sheets can also be shown semi-quantitatively (Budd and Smith, 1981). It is clear that as our basic knowledge of the flow and other physical properties of ice sheets improves, our ability to produce models of past and future ice sheets and their response to global forcing by, say, increased atmospheric $\mathrm{CO}_{2}$, will also be improved. However, this will result more from a better understanding of all the physical processes associated with the nourishment, flow, and wastage of present-day ice sheets than from further improvements in computing techniques. We need continued and increasing field studies including techniques such as core drilling and satellite studies of ice velocity and elevation changes. Studies in the field, laboratory, and computing rooms, will all require use of increasingly sophisticated techniques. The geochemical studies of the next section show the rewards of such advances.

\section{ICE-SHEET STUDIES AND GLOBAL SCIENCE}

\subsection{Introduction}

Fifty years ago we lacked adequate geographical knowledge of the characteristics of the Antarctic ice sheet. Apart from filling this gap, ice-sheet studies are now providing unique data of interest to a much wider group than polar scientists. Research into many global problems, especially in geophysics, shows that studies on a regional basis are of ten unsatisfactory. Answers do not become clear until a global pattern has been obtained. Furthermore, studies of polar ice sheets now provide certain data of global importance of a quality and/or quantity that are not available elsewhere.

We shall discuss the global importance of studies of ice sheets briefly in three major fields:

\section{(I) Global climate.}

(2) Geochemistry.

(3) Other geophysical sciences.

\subsection{Ice sheets and climatology}

Data from ice sheets are important to climatology in two ways. Ice sheets are a stabilizing component of the atmosphere-ocean-cryosphere system with a long response time that resists rapid changes. When dynamic modelling of climatic systems is fully developed, it must include the atmosphere, ocean, and ice sheets, and the interaction between these components. At present, dynamic models of these three major components are not yet sufficiently developed in their own medium, and this does not justify confidence in models linking all three in a joint model. On the longer time-scales of importance for global climatology, present models of ice dynamics may be considered as better developed than those of oceanography and possibly also those of atmospheric dynamics.

The second aspect important to climatology is provided by the very detailed record of past climates preserved in ice sheets on a time-scale ranging from annual variability to $10^{5}$ and even $10^{6}$ years. Internal layering in the Greenland ice sheet measured in isotopic profiling of ice cores has recorded annual variations of accumulation over the past 800 years (Hammer and others, 1978) and in future similar detail is likely over at least ten times that period. Similarly, proxy temperature records from $\delta^{18} \mathrm{O}$ and $8 \mathrm{D}$ profiles already cover the last $1.5 \times 10^{5}$ years, and this is likely to be extended to three to six times that figure during the next few years. Limitations to the accuracy of climatic 
parameters deduced from such records have been discussed at length by Robin (1983). In spite of these limitations, which are probably better understood than those of other proxy records, there appears to be no other marine or terrestrial evidence with comparable resolution on the time-scale of $10^{3}$ to over $10^{5}$ years.

The value of stratigraphic profiling of isotopic, chemical, ice-fabric, and other parameters was shown by Langway's (1970) discussion of results from a $411 \mathrm{~m}$ core at Site 2 in north-west Greenland. Isotopic profiles down to bedrock were first measured in Copenhagen by Dansgaard and others (1969) on a $1388 \mathrm{~m}$ ice core from Camp Century and by the same group (Johnsen and others, 1972) on a $2164 \mathrm{~m}$ ice core from Byrd Station. Drilling of these cores has been described by Hansen and Langway (1966) and Ueda and Garfield (1970), respectively.

In Figure 7, from Jouzel and others (1987), we show results obtained by scientists from France and the U.S.S.R. from studies of the $2083 \mathrm{~m}$ ice core from Vostok station, Antarctica. In this case, the $\delta \mathrm{D}$ (deuterium) isotope was measured instead of $\delta^{18} \mathrm{O}$ profile $\left(6 \mathrm{D} \approx 8 \delta^{18} \mathrm{O}\right)$. Measurements were made of the mean isotopic value along $1 \mathrm{~m}$ increments of the ice core to give high resolution and a clear indication of noise level along the core. Results of $6 \mathrm{D}$ in Figure 7 are expressed as temperature departures from present-day surface temperatures. Dating of the ice core was done entirely by glaciological modelling along similar lines to dating of isochrons in Figure 6. Comparable profiles from studies of marine cores also shown in Figure 7 were dated by quite independent methods of isotopic and magnetic age determination. The close correspondence with ages determined by glaciological dating gives confidence in the latest model of ice dynamics employed, which also included dependence of accumulation rate on atmospheric temperature.

\subsection{Atmospheric geochemistry}

In Figure 8 we show measurements of the $\mathrm{CO}_{2}$ content of air trapped in the ice core over the same period, using techniques developed by Oeschger and others (1982). No comparable data have been obtained from other media over such a time-scale. In view of concern over the increasing atmospheric $\mathrm{CO}_{2}$ levels due to Man's use of fossil fuels and the global warming due to the greenhouse effect of $\mathrm{CO}_{2}$ and other gases, the data of Figure 8 are of great practical value. They should help to show whether $\mathrm{CO}_{2}$ fluctuations are driven by climatic changes, or the reverse. The record shows that present atmospheric $\mathrm{CO}_{2}$ levels of around $345 \mathrm{ppm}$ by volume exceed any known levels during the past $150 \mathrm{ka}$

Studies of other gases, solids, and trace elements trapped in ice cores also provide a wonderfully detailed record of the Earth's atmosphere against a well-calibrated time-scale. For a study of individual events and interactions between different parameters, relative dating errors along sections of an ice core can be very small and of great value. This applies particularly to solids (volcanic ash, terrestrial dust) and conductivity ( $\left.\mathrm{SO}_{4}\right)$ changes which record particular events and can be related to climatic changes recorded in $6^{18} \mathrm{O}$ profiles (Hammer, 1980). Changes of concentration of major components of the atmosphere $\left(\mathrm{N}_{2}\right.$, $\mathrm{O}_{2}$, Ar, etc.) (Raynaud and Delmas, 1977) over $10^{5}$ years are known to be relatively small, and this provides a useful constraint on atmospheric modelling. The concentrations of certain trace elements such as ${ }^{10} \mathrm{Be}$ appear to be linked with action of cosmic rays on the upper atmosphere. They show that mean cosmic ray activity over long periods of time have not varied greatly over $10^{5}$ years, although some periods of enhanced activity seem likely (Yiou and others, (1985).

Studies of dust in polar ice cores have shown how the distribution of microparticles is related to location and weather systems (Thompson and Mosley-Thompson, 1982). Figure 8 shows how amounts of aluminium and sodium varied with time in the Vostok ice core of Figure 7. The aluminium curve is an indicator of dust from terrestrial sources, while the sodium records variations of marine salts (De Angelis and others, 1987). Peaks of Al result from increased aridity and exposure of continental shelves of mid southern latitudes, as well as changes of wind strengths

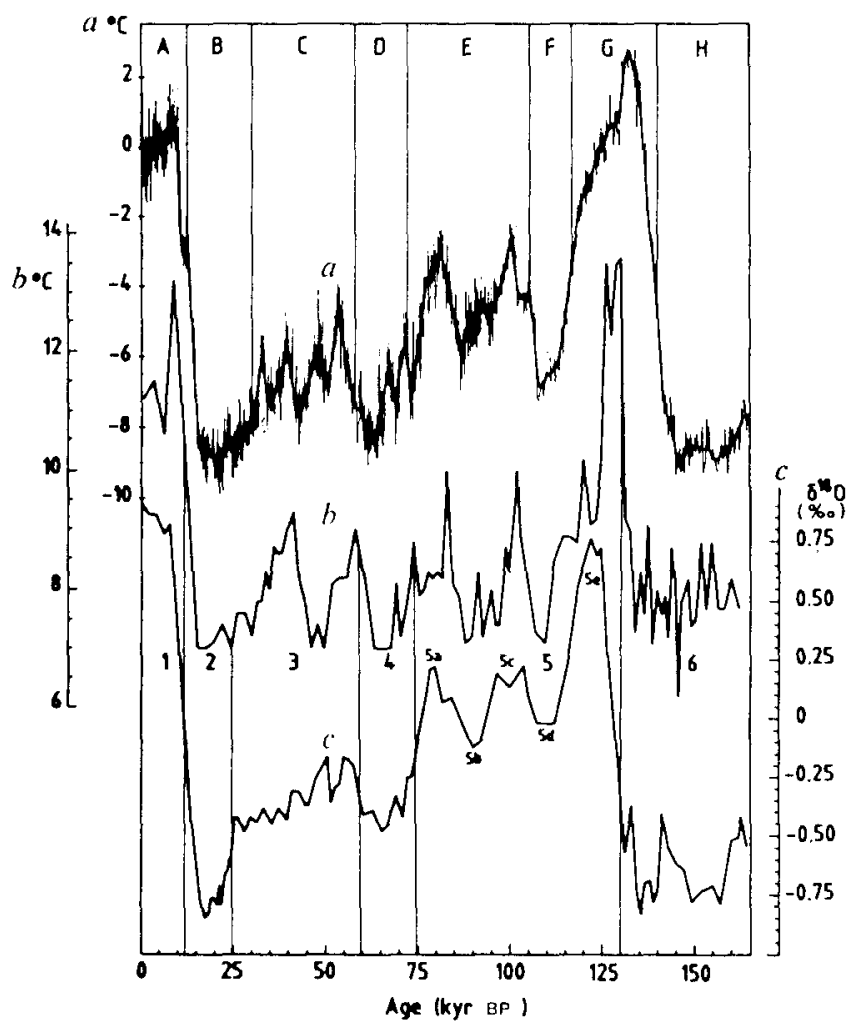

Fig. 7. a. Variation with time of the Vostok isotope temperature record in ${ }^{\circ} \mathrm{C}$ from $6 \mathrm{D}$ values. The present mean surface temperature of $-55.5^{\circ} \mathrm{C}$ is shown as $0^{\circ} \mathrm{C}$ on the scale. Temperatures are mean values over 100 years (thin lines) along with a smoothed curve (thick line).

b. Variation with time of summer sea-surface temperatures from core $R C I 1-120$ in the sub-polar Indian Ocean (from Martinson and others, 1987).

c. Variation with time of continental ice volume based on benthonic $\delta^{18} \mathrm{O}$ records (from Martinson and others, 1987). (Figure 7 is reproduced from Jouzel and others (1987) by permission of Nature.)

which are shown by both curves, as are the influence of changes of accumulation rate.

An extremely important aspect of geochemical studies of polar ice cores is their ability to provide a record of the global effect of man-made changes on the global atmosphere. $\mathrm{CO}_{2}$ has already been mentioned, while other greenhouse gases such as nitrous oxide $\left(\mathrm{NO}_{2}\right)$, methane $\left(\mathrm{CH}_{4}\right)$, and chlorofluorocarbons have also been measured in polar ice cores. One great advantage of polar ice cores is that one can measure the variability of these components from natural causes before Man had a significant effect. It is essential to know this background variability before assessing the significance of shorter-period historical records and the global temperature effects of greenhouse gases. Man's increasing injection of lead into the atmosphere from automobile exhausts since 1950 is well recorded in ice cores from Greenland (Murozumi and others, 1969). There are no comparable increases of lead in the Antarctic ice sheet, where observed short-period fluctuations are explained by volcanic activity.

The relationship between changes of atmospheric composition of trace elements and gases to those trapped in ice sheets studied by Wolff and Peel (1985) removes one further uncertainty of interpretation of ice-core data as a long-term historic record of atmospheric changes.

Ice coring is logistically difficult and expensive, and the analysis of minute quantities of trace elements in the laboratory demands sophisticated techniques with a very high quality of processing. The results are of such wide importance that further expansion of these studies seems inevitable as Man's concern over modification of the Earth's atmosphere increases.

\subsection{Ice sheets and global geophysics}

The discovery of a number of meteoritic fragments on 

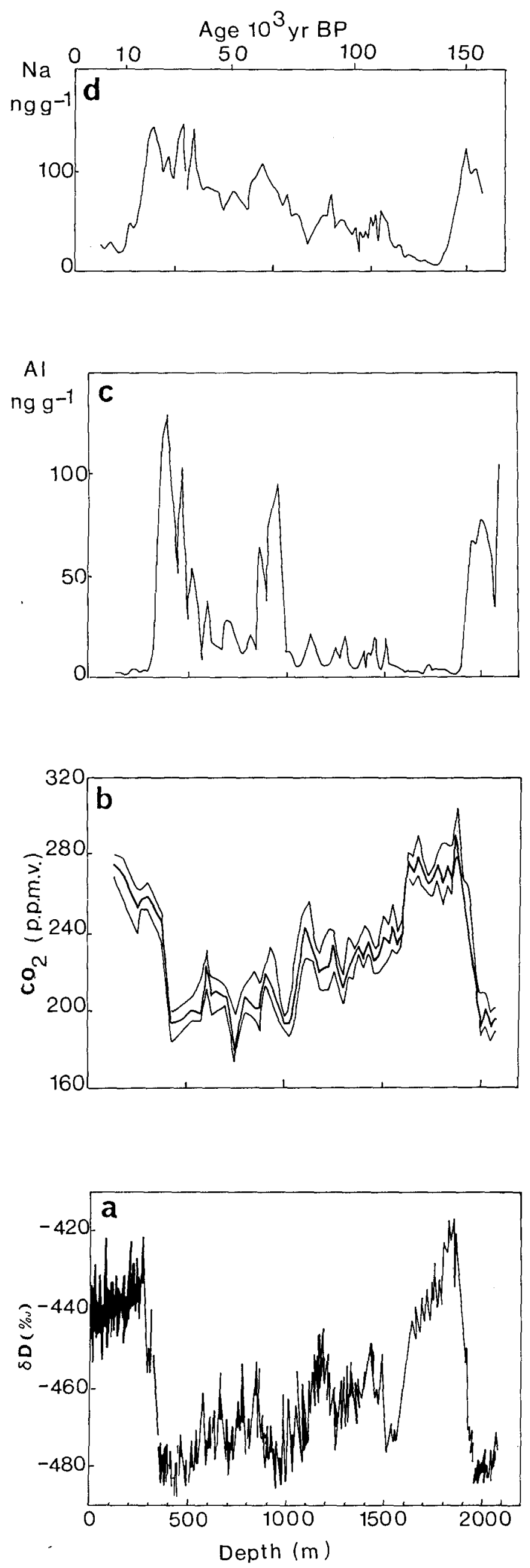

a limited area of bare ice near the Yamato Mountains (Yoshida and others, 1971) has led to specific searches of other areas where ice flow and ablation could produce surface concentrations of this material. As a result, more meteoritic fragments have been found on the Antarctic ice sheet during the last two decades than the total collected from elsewhere on Earth. Furthermore, since these have remained encased in cold ice since falling on Earth, their chemical purity has been little changed over many millennia compared with similar changes of old meteoritic material from terrestrial or marine sources. Meteorites from the Antarctic ice sheet, now under curatorship in the Smithsonian Museum, Washington D.C., have been distributed to experts in many countries for detailed analysis. This is another encouraging example of serendipity in the study of ice sheets.

Similar carriage and concentration by ice of diatoms has probably confused rather than helped glacial geologists in another field, the interpretation of old diatoms found in the Sirius Formation - altitude $\sim 2000 \mathrm{~m}$ in the Transantarctic Mountains. It is difficult to explain their location from their terrestrial (lacustrine) or marine origin and by transport by ice without a drastic modification of concepts on the history of Antarctic tectonics and glaciation. This example provides a warning that some basic geophysical and glaciological concepts need further verification.

Carriage of vast loads of basal moraine by polar ice sheets and its eventual deposition on the ocean floor provides valuable information to marine geologists on the global climatic and geological records - another rapidly expanding field of research. However, glaciological knowledge of processes of erosion and transport of moraine by ice is still very limited and needs much improvement (see Boulton, 1987)

Isostatic loading and unloading of ice sheets on the Earth's crust has provided a prime source of data on the elasticity of the lithosphere and of the viscosity of the layers beneath (Lliboutry, 1971). A better appreciation of the mass of former ice sheets has significantly improved such calculations.

On a broader front, the study of the dynamics of polar ice sheets provides the largest-scale example of a material of known physical composition (ice plus around $0.01 \%$ by weight of air) whose physical properties determined in the laboratory can be related to the continental scale deformation of the same material on Earth. Although there are some basic differences with rock-forming minerals, many physical principles that have been shown to apply on ice sheets may well be applied to the solid Earth. Application of glaciologically derived concepts to studies of deformation of the Earth's mantle (Weertman, 1962) provide an example of such cross fertilization of ideas between solid Earth scientists and ice-sheet glaciologists.

Propagation of water-filled crevasses to the base of glaciers due to the greater density of water than ice has its counterpart in the upward opening of cracks in the Earth's crust due to the lower density of molten magma than the surrounding rock. Weertman (1971) has tackled both problems with the same theory.

Interaction between ice shelves and oceans is another field where data from radio-sounding of ice shelves (Robin and others, 1983) and that from salinity-temperature-depth

Fig. 8, Measured parameters on the Vostok ice core plotted against depth on the bottom scale and against time on the upper (non-linear) scale.

a. Deuterium content (in to w.r.t. SMOW). These data are interpreted as temperature in Figure $7 a$ (from Jouzel and others, 1987).

b. Carbon dioxide concentrations (ppm volume). Dots show the best estimates of $\mathrm{CO}_{2}$ and the envelope indicates the uncertainty (from Barnola and others, 1987).

c. Aluminium concentration ( $\mathrm{g} \mathrm{g}^{-1}$ ) (from De Angelis and others, 1987).

d. Marine sodium concentration ( $n g g^{-1}$ ) (from De Angelis and others, 1987). 
profiling of ocean waters (Foldvik and others, 1985) provide complementary evidence about processes responsible for formation of the cold, dense Antarctic bottom water that spreads to beyond the Equator in the Atlantic Ocean.

These are a few examples that show the importance of the studies of ice sheets to our understanding of the planet on which we live - and even to that of any other planets with ice caps. Their value lies both in provision of data of global significance that cannot be found from any other source as well as their broader value in the study of the mechanics of deformation of vast, terrestrial solid masses such as the Earth's mantle.

\section{CONCLUSION}

Through the activities of the Society over the past 50 years, and especially through its role in bringing glaciologists together at Symposia and in publishing glaciological material so effectively, the International Glaciological Society has had a vastly greater impact on knowledge - both academic and practical - than the few skiers responsible for its formation in 1938 could have imagined.

\section{REFERENCES}

Angelis, M. de, and others. 1987. Aerosol concentrations over the last climatic cycle $(160 \mathrm{kyr})$ from an Antarctic ice core, by $M$. de Angelis, N.I. Barkov, and V.N. Petrov. Nature, Vol. 325, No. 6102, p. 318-21.

Bakayev, V.G., ed. 1966. Atlas Antarktiki [Atlas of Antarctica]. Moscow and Leningrad, Glavnoye Upravleniye Geodezii i Kartografii.

Barnola, J.M., and others. 1987. Yostok ice core provides 160,000-year record of atmospheric $\mathrm{CO}_{2}$, by J.M. Barnola, D. Raynaud, Y.S. Korotkevich, and C. Lorius. Nature, Vol. 329, No. 6138, p. 408-14.

Bauer, A. 1955. Über die in der heutigen Vergletscherung der Erde als Eis gebundene Wassermasse. Eiszeitalter und Gegenwart, Bd. 6, p. 60-70.

Bauer, A., and others. 1968. Missions aériennes de reconnaissance au Groenland $1957-58$, by A. Bauer, M. Baussart, M. Carbonnell, P. Kasser, P. Perroud, and A. Renaud. Meddelelser om Grønland, Bd. 173, Nr. 3.

Benson, C.S. 1961. Stratigraphic studies in the snow and firn of the Greenland ice sheet. Folia Geographica Danica, Tom. 9, p. 13-37.

Bentley, C.R. 1964. The structure of Antarctica and its ice cover. (In Oddishaw, H., ed. Research in geophysics. Vol. 2. Cambridge, MA, M.I.T. Press, p. 335-89.)

Blankenship, D.D., and others. 1986. Seismic measurements reveal a saturated porous layer beneath an active Antarctic ice stream, by D.D. Blankenship, C.R. Bentley, S.T. Rooney, and R.B. Alley. Nature, Vol. 322, No. 6074, p. 54-57.

Bogorodskiy, V.V., and others. 1985. Radioglaciology, by V.V. Bogorodskiy, C.R. Bentley, and P.E. Gudmandsen. Dordrecht, D. Reidel Publishing Co.

Boulton, G.S. 1987. Progress in glacial geology during the last fifty years. Journal of Glaciology. Special Issue, $\mathrm{p}$. 25-32.

Brooks, R.L., and others. 1978. Ice sheet topography by satellite altimetry, by R.L. Brooks, W.J. Campbell, R.O. Ramseier, H.R. Stanley, and H.J. Zwally. Nature, Vol. 274, No. 5671, p. 539-43.

Budd, W.F. 1966. The dynamics of the Amery Ice Shelf. Journal of Glaciology, Vol. 6, No. 45, p. 335-58.

Budd, W.F., and Smith, I.N. 1981. The growth and retreat of ice sheets in response to orbital radiation changes. [Union Géodésique et Géophysique Internationale. Association Internationale des Sciences Hydrologiques.] Sea Level, Ice, and Climatic Change. Proceedings of the Symposium held 7-8 December 1979 during the 17th General Assembly of the International Union of Geodesy and Geophysics, Canberra, p. 369-409. (IAHS Publication No. 131.)
Budd, W.F., and Smith, I.N. 1985. The state of balance of the Antarctic ice sheet; an updated assessment 1984. (In Glaciers, ice sheets and sea level: effect of a $\mathrm{CO}_{2}$-induced climatic change; report of a workshop held in Seattle, Washington, September 13-15, 1984. Washington, DC, U.S. Department of Energy, p. 172-77.)

Budd, W.F., and Young, N.W. 1983. Application of modelling techniques to measured profiles of temperatures and isotopes. (In Robin, G. de Q., ed. The climatic record in polar ice sheets. Cambridge, Cambridge University Press, p. 150-77.)

Budd, W.F., and others. 1971. Derived physical characteristics of the Antarctic ice sheet, by W.F. Budd, D Jenssen, and $U$. Radok. ANARE Interim Reports. Ser. A(IV), Glaciology, Publication No. 120.

Budd, W.F., and others. 1982. Derived physical characteristics of the Greenland ice sheet. Mark 1, by W.F. Budd, T.H. Jacka, D. Jenssen, U. Radok, and N.W. Young. Parkville, Victoria, University of Melbourne. Meteorology Department. (Publication No. 23.)

Buynitskiy, V.Kh. 1960. Ob'yem i balans veshchestva v lednikovom shchite Antarktidy [Volume and mass balance of the Antarctic ice sheet]. Vestnik Leningradskogo Universiteta, No. 24, p. 74-82. (Seriya Geologii i Geografii No. 4.)

Chang, T.C., and others. 1976. Microwave emission from snow and glacier ice, by T.C. Chang, P. Gloersen, T. Schmugge, T.T. Wilheit, and H.J. Zwally. Journal of Glaciology, Vol. 16, No. 74, p. 23-39.

Colbeck, S. 1980. Dynamics of snow and ice masses. New York, etc., Academic Press.

Crary, A.P. 1966. Mechanism for fiord formation indicated by studies of an ice-covered inlet. Geological Society of America. Bulletin, Vol. 77, No. 9, p. 911-29.

Croll, J. 1879. Thickness of the Antarctic ice and its relations to that of the glacial epoch. Quarterly Journal of Science, Vol. 9, p. 1-34.

Daly, R.A. 1934. The changing world of the ice age. New Haven, Yale University Press.

Dansgaard, W., and others. 1969. One thousand centuries of climatic record from Camp Century on the Greenland ice sheet, by W. Dansgaard, S. Johnsen, and J. Moller. Science, Vol. 166, No. 3903, p. 377-81.

Demorest, M. 1943. Ice sheets. Bulletin of the Geological Society of America, Vol. 54, No. 3, p. 363-99.

Doake, C.S.M. 1976. Thermodynamics of the interaction between ice shelves and the sea. Polar Record, Vol. 18, No. 112 , p. $37-41$.

Doake, C.S.M. 1985. Antarctic mass balance: glaciological evidence from Antarctic Peninsula and Weddell Sea sector. (In Glaciers, ice sheets, and sea level: effect of a $\mathrm{CO}_{2}$-induced climatic change; report of a workshop held in Seattle, Washington, September 13-15. 1984. Washington, DC, U.S. Department of Energy, p. 197-209.)

Donn, W.L., and others. 1962. Pleistocene ice volumes and sea level lowering, by W.L. Donn, W.R. Farrand, and M. Ewing. Journal of Geology, Vol. 70, No. 2, p. 206-14.

Dorrer, E., and others. 1969. Geodetic results of the Ross Ice Shelf survey expeditions, $1962-63$ and $1965-66$, by E. Dorrer, W. Hofmann, and W. Seufert. Journal of Glaciology, Vol. 8, No. 52, p. 67-90.

Dorsey, N.E. 1940. Properties of ordinary water substance in all its phases: water-vapor, water, and all the ices. New York, Reinhold Publishing Corporation.

Drew, A.R., and Whillans, I.M. 1984. Measurement of surface deformation of the Greenland ice sheet by satellite tracking. Annals of Glaciology, Vol. 5, p. 51-55.

Drewry, D.J., ed. 1983. Antarctica: glaciological and geophysical folio. Cambridge, University of Cambridge. Scott Polar Research Institute.

Engelhardt, H., and Determann, J. 1987. Borehole evidence for a thick layer of basal ice in the central Ronne Ice Shelf. Nature, Vol. 327, No. 6120, p. 318-19.

Fletcher, N.H. 1970. The chemical physics of ice. Cambridge, Cambridge University Press.

Flint, R.F. 1947. Glacial geology and the Pleistocene epoch. New York, John Wiley and Sons.

Foldvik, A., and others. 1985. Circulation and water masses on the southern Weddell Sea shelf, by A. Foldvik, T. Kvinge, and T. Tørresen. (In Jacobs, S.S., ed. Oceanology 
of the Antarctic continental shelf. Washington, DC, American Geophysical Union, p. 5-20. (Antarctic Research Series Vol. 43.))

Garfield, D. E., and Ueda, H.T. 1976. Resurvey of the "Byrd" Station, Antarctica, drill hole. Journal of Glaciology, Vol. 17, No. 75 , p. 29-34.

Giovinetto, M.B., and Bentley, C.R. 1985. Surface balance in ice drainage systems of Antarctica. Antarctic Journal of the United States, Vol. 20, No. 4, p. 6-13.

Glen, J.W. 1955. The creep of polycrystalline ice. Proceedings of the Royal Society, Ser. A, Vol. 228, No. 1175 , p. $519-38$.

Gould, L.M. 1940. Glaciers of Antarctica. Proceedings of the American Philosophical Society, Vol. 82, No. 5, p. 835-70.

Hamley, T.C., and others, 1985. Mass-balance and ice-flow law parameters for East Antarctica, by T.C. Hamley, I.N. Smith, and N.W. Young. Journal of Glaciology, Vol. 31, No. 109 , p. 334-39.

Hammer, C.U. 1980. Acidity of polar ice cores in relation to absolute dating, past volcanism and radio-echoes. Journal of Glaciology, Vol. 25, No. 93, p. 359-72.

Hammer, C.U., and others. 1978. Dating of Greenland ice cores by flow models, isotopes, volcanic debris, and continental dust, by C.U. Hammer, H.B. Clausen, W. Dansgaard, N. Gundestrup, S. Johnsen, and N. Reeh. Journal of Glaciology, Vol. 20, No. 82, p. 3-26.

Hansen, B.L., and Langway, C.C., jr. 1966. Deep core drilling in ice and core analysis at Camp Century, Greenland, 1961-66. Antarctic Journal of the United States, Vol. 1, No. 5, p. 207-08.

Hays, J.D., and others. 1966. Variations in the Earth's orbit: pacemaker of the ice ages, by J.D. Hays, J. Imbrie, and N.J. Shackleton. Science, Vol. 194, No. 4270, p. 1121-32.

Hobbs, P.V. 1974. Ice physics. Oxford, Clarendon Press.

Holtzscherer, J.J., and Robin, G. de Q. 1954. Depth of polar ice caps. Geographical Journal, Vol. 120, Pt. 2, p. 193-202.

Hutter, K. 1983. Theoretical glaciology; material science of ice and the mechanics of glaciers and ice sheets. Dordrecht, etc., D. Reidel Publishing Company/Tokyo, Terra Scientific Publishing Company.

Jacobs, S.S., and others. 1985. Origin and evolution of water masses near the Antarctic continental margin: evidence from $\mathrm{H}_{2}{ }^{18} \mathrm{O} / \mathrm{H}_{2}{ }^{16} \mathrm{O}$ ratios in sea water, by S.S. Jacobs, G. Fairbanks, and Y. Horibe. (In Jacobs, S.S., ed. Oceanology of the Antarctic continental shelf. Washington, DC, American Geophysical Union, p. 59-85. (Antarctic Research Series Vol. 43.))

Jenssen, D. 1983. Elevation and climatic changes from total gas content and stable isotopic measurements. (In Robin, G. de Q., ed. The climatic record in polar ice sheets. Cambridge, Cambridge University Press, p. 138-44.)

Jenssen, D., and Campbell, J.A. 1983. Heat conduction studies. (In Robin, G. de Q., ed. The climatic record in polar ice sheets. Cambridge, Cambridge University Press, p. 125-38.)

Johnsen, S.J., and others. 1972. Oxygen isotope profiles through the Antarctic and Greenland ice sheets, by S.S. Johnsen, W. Dansgaard, H.B. Clausen, and C.C. Langway, jr. Nature, Vol. 235, No. 5339, p. 429-34.

Jouzel, J., and others. 1987. Vostock ice core: a continuous isotope temperature record over the last climatic cycle (160,000 years), by J. Jouzel [and 6 others]. Nature, Vol. 329, No. 6138, p. 403-08.

Kosack, H.-P. 1956. Zur frage des Wasserhaushalts in der Antarktis. Polarforschung, Bd. 3, Ht. 1/2, 1954, p. 286-94.

Krüger, H.K.E. 1929. Gesteinkörper und Inlandeis Grönlands in ihrer gegenseitigen Beziehung und Auswirkung. Zeitschrift für Gletscherkunde, Bd. 17, p. 1-32.

Langway, C.C., jr. 1970. Stratigraphic analysis of a deep ice core from Greenland. Boulder, CO, Geological Society of America. (Special paper 125.)

Lindsay, M. 1935. Sledge: the British Trans-Greenland Expedition 1934. London, Cassell.

Lliboutry, L. 1964-65. Traité de glaciologie. Tomes 1 et 2. Paris, Masson.
Lliboutry, L.A. 1971. Rheological properties of the asthenosphere from Fennoscandian data. Journal of Geophysical Research, Vol. 76, No. 5, p. 1433-46.

Loewe, F. 1935. The exploration of the Greenland ice-cap, 1929-1934. Scottish Geographical Magazine, Vol. 51, No. 6, p. 347-53.

Lorius, C., and others. 1985. A 150,000 year climatic record from Antarctic ice, by $C$. Lorius [and 6 others]. Nature, Vol. 316, No. 6029, p. 591-96.

MacDonald, W.R. 1976. Glaciology in Antarctica. U.S. Geological Survey. Professional Paper 929, p. 194-95.

McIntyre, N.F. 1985. The dynamics of ice-sheet outlets. Journal of Glaciology, Vol. 31, No. 108, p. 99-107.

Martinson, D.G., and others. 1987. Age dating and orbital theory of the ice ages: development of a high-resolution 0 to 300,000 -year chronostratigraphy, by D.G. Martinson, N.G. Pisias, J.D. Hays, J. Imbrie, T.C. Moore, $j r$, and N.J. Shackleton. Quaternary Research, Vol. 27, No. 1, p. 1-29.

Meinardus, W. 1938. Handbuch der Klimatologie. Bd. 4, Teil U. Klimakunde der Antarktis. Berlin, Gebrüder Borntraeger.

Mock, S.J., and Weeks, W.F. 1965. The distribution of ten-meter snow temperatures on the Greenland ice sheet. CRREL Research Report 170.

Morgan, V.I. 1972. Oxygen isotope evidence for bottom -freezing on the Amery Ice Shelf. Nature, Vol. 238, No. 5364, p. 393-94.

Murozumi, M., and others. 1969. Chemical concentrations of pollutant lead aerosols, terrestrial dusts and sea salts in Greenland and Antarctic snow strata, by $\mathbf{M}$. Murozumi, T.J. Chow, and C. Paterson. Geochimica et Cosmochimica Acta, Vol, 33, No. 10, p. 1247-94.

Nye, J.F. 1951. The flow of glaciers and ice sheets as a problem in plasticity. Proceedings of the Royal Society, Ser. A, Vol. 207, p. 554-72.

Nye, J.F. 1952. The mechanics of glacier flow. Journal of Glaciology, Vol. 2, No. 12, p. 82-93.

Nye, J.F. 1959. The motion of ice sheets and glaciers. Journal of Glaciology, Vol. 3, No. 26, p. 493-507.

Odell, N.E. 1952. Antarctic glaciers and glaciology. (In Simpson, F.A., ed. The Antarctic today. Wellington, A.H and A.W. Reed/New Zealand Antarctic Society, p. 25-55.)

Oeschger, $\mathrm{H}$., and others. 1982. Atmospheric $\mathrm{CO}_{2}$ content in the past deduced from ice-core analyses, by $\mathrm{H}$. Oeschger, B. Stauffer, J. Neftel, J. Schwander, and R. Zumbrunn. Annals of Glaciology, Vol. 3, p. 227-32.

Paterson, W.S.B. 1981. The physics of glaciers. Second edition. Oxford, etc., Pergamon Press. (Pergamon International Library.)

Perutz, M.F. 1950. Direct measurement of the velocity distribution in a vertical profile through a glacier. Journal of Glaciology, Vol. 1, No. 7, p. 382-83.

Potter, J.R., and Paren, J.G. 1985. Interaction between ice shelf and ocean in George VI Sound, Antarctica. (In Jacobs, S.S., ed. Oceanology of the Antarctic continental shelf. Washington, DC, American Geophysical Union, p. 35-58.) (Antarctic Research Series Vol. 43.))

Poulter, T.C. 1947. Seismic measurements on the Ross shelf ice. Transactions of the American Geophysical Union, Vol. 28, No. 2, p. 162-70; No. 3, p. 267-84

Pounder, E.R. 1965. Physics of ice. Oxford, etc., Pergamon Press.

Radok, U., and others. 1986. On the surging potential of polar ice streams. Part IV. Antarctic ice accumulation basins and their main discharge regions, by U. Radok, T.J. Brown, I.N. Smith, W.F. Budd, and D. Jenssen. Washington, DC, Department of Energy. (Report DE/ER/60197-5.)

Raynaud, D., and Delmas, R. 1977. Composition des gaz contenus dans la glace polaire. [Union Géodésique et Géophysique Internationale. Association Internationale des Sciences Hydrologiques. Commission des Neiges et Glaces.] Symposium. Isotopes et Impuretés dans les Neiges et Glaces. Actes du Colloque de Grenoble, août/septembre 1975 , p. 377-81. (IAHS-AISH Publication No. 118.)

Raynaud, D., and Lebel, B. 1979. Total gas content and surface elevation of polar ice sheets: new evidence. Nature, Vol. 281, No. 5729, p. 289-91. 
Reeh, N. 1985. Greenland ice-sheet mass balance and sea-level change. (In Glaciers, ice sheets, and sea level: effect of a $\mathrm{CO}_{2}$-induced climatic change; report of a workshop held in Seatle, Washington, September 13-15, 1984. Washington, DC, U.S. Department of Energy, p. 155-71.

Rigsby, G.P. 1958. Effect of hydrostatic pressure on velocity of shear deformation of single ice crystals. Journal of Glaciology, Vol. 3, No. 24, p. 273-78.

Ritz, C., and others. 1982. Analysis of a $870 \mathrm{~m}$ deep temperature profile at Dome C, by C. Ritz, L. Lliboutry and C. Rado. Annals of Glaciology, Vol. 3, p. 284-89.

Robin, G. de Q. 1958. Glaciology. III. Seismic shooting and related investigations. Norwegian-British-Swedish Antarctic Expedition, 1949-52. Scientific Results, Vol. 5.

Robin, G. de Q. 1970. Stability of ice sheets as deduced from deep temperature gradients. [Union Géodésique et Géophysique Internationale. Association Internationale d'Hydrologie Scientifique.] [International Council of Scientific Unions. Scientific Committee on Antarctic Research. International Association of Scientific Hydrology. Commission of Snow and Ice.] International Symposium on Antarctic Glaciological Exploration (ISAGE), Hanover, New Hampshire, U.S.A., 3-7 September 1968, p. 141-51. [(Publication No. 86 [de l'Association Internationale d'Hydrologie Scientifique].)]

Robin, G. de Q. 1977. Ice cores and climatic change. Philosophical Transactions of the Royal Society of London, Ser. B, Vol. 280, No. 972, p. 143-68.

Robin, G. de Q., ed. 1983. The climatic record in polar ice sheets. Cambridge, Cambridge University Press.

Robin, G. de Q., and Millar, D.H.M. 1982. Flow of ice sheets in the vicinity of subglacial peaks. Annals of Glaciology, Vol. 3, p. 290-94.

Robin, G. de Q., and others. 1969. Interpretation of radio echo sounding in polar ice sheets, by G. de Q. Robin, S. Evans, and J.T. Bailey. Philosophical Transactions of the Royal Society of London. Ser. A, Vol. 265, No. 1166, p. 437-505.

Robin, G. de Q., and others. 1977. International studies of ice sheet and bedrock, by $G$. de Q. Robin, D.J. Drewry, and D.T. Meldrum. Philosophical Transactions of the Royal Society of London, Ser. B, Vol. 279, No. 963, p. $185-96$

Robin, G. de Q., and others. 1983. Regime of the Filchner and Ronne ice shelves, Antarctica, by $G$. de Q. Robin, C.S.M. Doake, H. Kohnen, R.D. Crabtree, S.R. Jordan, and D. Möller. Nature, Vol. 302, No. 5909, p. 582-86.

Ross, Sir J.C. 1847. A voyage of discovery and research in the southern and Antarctic regions during the years 1839-43. London, John Murray.

Sanderson, T.J.O. 1979. Equilibrium profile of ice shelves. Journal of Glaciology, Vol. 22, No. 88, p. 435-60.

Schytt, V. 1957. Glaciology. II. Snow studies at Maudheim Norwegian-British-Swedish Antarctic Expedition, 1949-52. Scientific Results, Vol. 4A.

Schytt, V. 1974. Inland ice sheets, recent and Pleistocene Geologiska Föreningens $i$ Stockholm Förhandlingar, Vol. 96, Pt. 4, p. 299-309.

Shabtaie, S., and Bentley, C.R. 1987. West Antarctic ice streams draining into the Ross Ice Shelf: configuration and mass balance. Journal of Geophysical Research, Vol. 92, No. B2, p. 1311-36.

Shumskiy, P.A. 1964. Principles of structural glaciology. New York, Dover Publications.

Sorge, E. 1933. Die Eisdickenmessungen auf der Vorexpedition und die Eisdickenmessung in Eismitte auf der Hauptexpedition. Wissenschaftliche Ergebnisse der Deutschen Grönland-Expedition Alfred Wegener 1929 und 1930/31. Bd. 2. Leipzig, F.A. Brockhaus, p. 125-60.

Sorge, E. 1935. Glaziologische Untersuchungen in Eismitte. Wissenschaftliche Ergebnisse der Deutschen GrönlandExpedition Alfred Wegener 1929 und 1930/1931. Bd. 3, Leipzig, F.A. Brockhaus, p. 62-270.

Streiff-Becker, R. 1938. Zur Dynamik des Firneises. Zeitschrift für Gletscherkunde, Bd. 26, p. 1-21.

Swithinbank, C.W.M. 1963. Ice movement of valley glaciers flowing into the Ross Ice Shelf, Antarctica. Science, Vol. 141, No. 3580, p. 523-24.
Swithinbank, C.W.M. 1985. A distant look at the cryosphere. Advances in Space Research, Vol. 5, No. 6, p. 263-74.

Thiel, E.C. 1962. The amount of ice on planet Earth. (In Wexler, H., and others, eds. Antarctic research. The Matthew Fontaine Maury Memorial Symposium. Edited by H. Wexler, M.J. Rubin, and J.E. Caskey, jr. Washington, DC, American Geophysical Union, p. 172-75. (Geophysical Monograph No. 7.))

Thomas, R.H. 1973[a]. The creep of ice shelves: interpretation of observed behaviour. Journal of Glaciology, Vol. 12, No. 64, p. 55-70.

Thomas, R.H. 1973[b]. The creep of ice shelves: theory. Journal of Glaciology, Vol. 12, No. 64, p. 45-53.

Thomas, R.H., and others. In press. Glaciological studies on the Ross Ice Shelf, Antarctica, 1973-1978, by R.H. Thomas, D.R. MacAyeal, D.H. Eilers, and D.R. Gaylord. (In Bentley, C.R., and Hayes, D.E., eds. The Ross Ice Shelf: glaciology and geophysics. Washington, DC, American Geophysical Union, p. 21-53. (Antarctic Research Series Vol. 42.)) [Preprint 1984.]

Thompson, L.G., and Mosley-Thompson, E. 1982. Spatial distribution of microparticles within Antarctic snowfall Annals of Glaciology, Vol. 3, p. 300-06.

Ueda, H.T., and Garfield, D.E. 1970. Deep core drilling at Byrd Station, Antarctica. [Union Géodésique et Géophysique Internationale. Association Internationale d'Hydrologie Scientifique.] [International Council of Scientific Unions. Scientific Committee on Antarctic Research. International Association of Scientific Hydrology. Commission of Snow and Ice.] International Symposium on Antarctic Glaciological Exploration (ISAGE), Hanover, New Hampshire, U.S.A., 3-7 September 1968, p. 53-62. I(Publication No. 86 [de l'Association Internationale d'Hydrologie Scientifique].)]

Wade, F.A. 1945. The physical aspects of the Ross shelf ice. Proceedings of the American Philosophical Society, Vol. 89 , No. 1, p. 160-73.

Wager, L.R. 1933. The form and age of the Greenland ice cap. Geological Magazine, Vol. 70, No. 4, p. 145-56.

Waite, A.H., and Schmidt, S.J. 1962. Gross errors in height indication from pulsed radar altimeters operating over thick ice or snow. Proceedings of the Institute of Radio Engineers, Vol. 50, p. 1515-20.

Weertman, J. 1957[a]. Deformation of floating ice shelves. Journal of Glaciology, Vol. 3, No. 21, p. 38-42.

Weertman, J. 1957[b]. On the sliding of glaciers. Journal of Glaciology, Vol. 3, No. 21, p. 33-38.

Weertman, J. 1962. Mechanism for continental drift. Journal of Geophysical Research, Vol. 67, No. 3, p. 1133-39.

Weertman, J. 1964. Rate of growth or shrinkage of nonequilibrium ice sheets. Journal of Glaciology, Vol. 5, No. 38 , p. $145-58$.

Weertman, J. 1971. Velocity at which liquid-filled cracks move in the Earth's crust or in glaciers. Journal of Geophysical Research, Vol. 76, No. 35, p. 8544-53. Whillans, I.M. 1976. Radio-echo layers and the recent stability of the West Antarctic ice sheet. Nature, Vol. 264 , No. 5582 , p. 152-55.

Whillans, I.M. 1983. Ice movement. (In Robin, G. de Q., ed. The climatic record in polar ice sheets. Cambridge, Cambridge University Press, p. 70-77.)

Whillans, I.M., and Johnsen, S.J. 1983. Longitudinal variations in glacial flow: theory and test using data from the Byrd Station strain network, Antarctica. Journal of Glaciology, Vol. 29, No. 101, p. 78-97.

Williams, R.S., $j r$, and others. 1983. Blue ice, meteorites, and satellite imagery in Antarctica, by R.S. Williams, $j r$, T.K. Meunier, and J.G. Ferrigno. Polar Record, Vol. 21 , No. 134, p. 493-504.

Wilson, A.T. 1964. Origin of ice ages: an ice shelf theory for Pleistocene glaciation. Nature, Vol. 201, No. 4915, p. 147-49.

Wolff, E.W., and Peel, D.A. 1985. The record of global pollution in polar snow and ice. Nature, Vol. 313, No 6003 , p. $535-40$.

Wright, C.S., and Priestley, R.E. 1922. British (Terra Nova) Antarctic Expedition 1910-1913. Glaciology. London, Harrison and Sons. 
Wright, W.B. 1937. The Quaternary ice age. Second edition. London, Macmillan.

Yiou, F., and others. $1985 .{ }^{10} \mathrm{Be}$ in ice at Vostok, Antarctica, during the last climatic cycle, by F. Yiou, G.M. Raisbeck, D. Bourles, C. Lorius, and N.I. Barkov. Nature, Vol. 316, No. 6029, p. 616-17.

Yoshida, M., and others. 1971. Discovery of meteorites near Yamato Mountains, East Antarctica, by M. Yoshida, H. Ando, K. Omoto, R. Naruse, and Y. Ageta. Antarctic Record, No. 39, p. 62-65.

Zotikov, I.A. 1963. Bottom melting in the central zone of the ice shield on the Antarctic continent and its influence upon the present balance of the ice mass. Bulletin of the International Association of Scientific Hydrology, $8^{\mathrm{e}}$ Année, No. 1, p. 36-44.

Zwally, H.J. 1984. Observing polar-ice variability. Annals of Glaciology, Vol. 5, p. 191-98.

Zwally, H.J., and others. 1983. Surface elevation contours of Greenland and Antarctic ice sheets, by H.J. Zwally, R.A Bindschadler, A.C. Brenner, T.V. Martin, and R.H. Thomas. Journal of Geophysical Research, Vol. 88, No. C3, p. 1589-96. 